\title{
الأقلتات غير المسلمة في المجتمع المسلم
}

دراسة انثرويولوجية لمنهجية الرسول (صلي الله عليه وسلم ) في السلم المعلئ

\author{
الاجتماعي

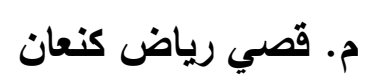

جامعة الموصل - كلية الآداب - قسم علم الاجتماع

qusayryaad@yahoo.com

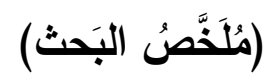

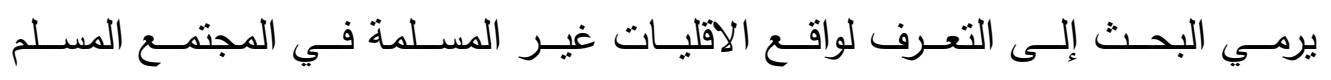

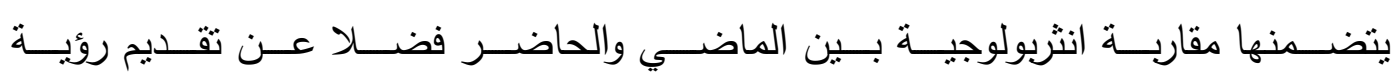

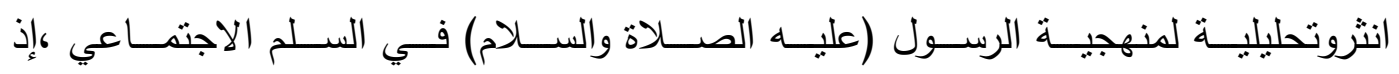

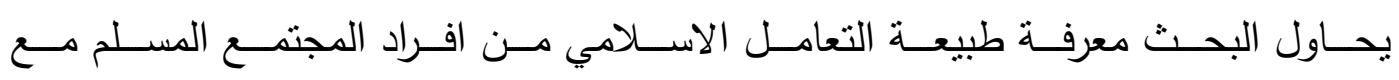

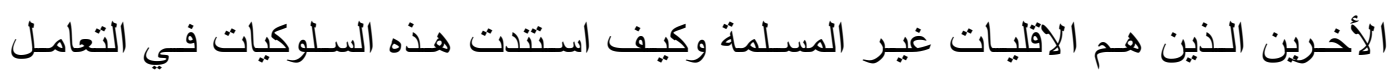

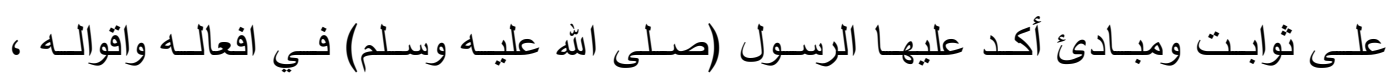

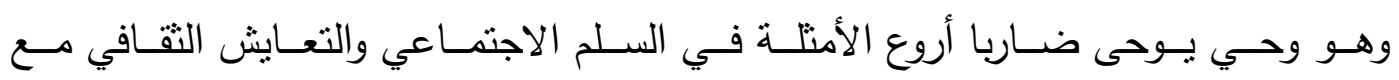

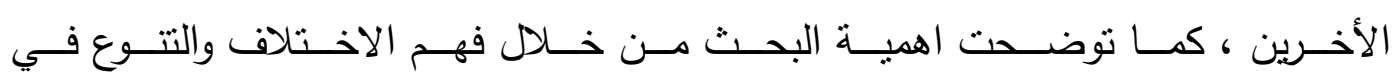

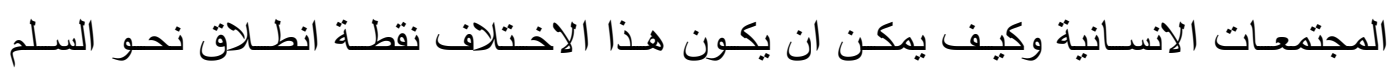

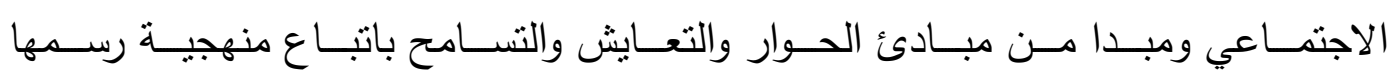

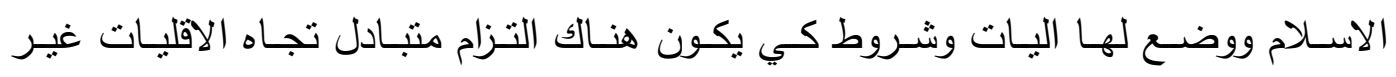

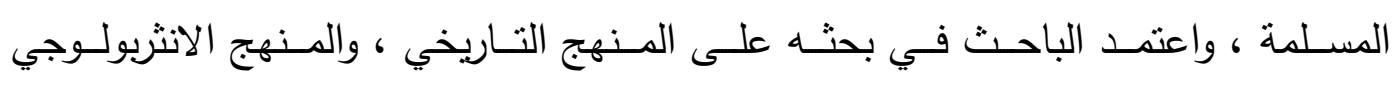

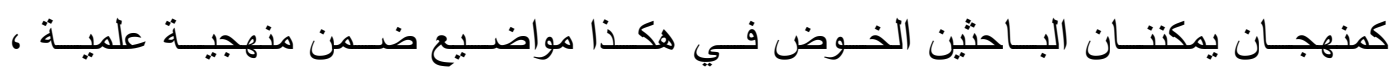

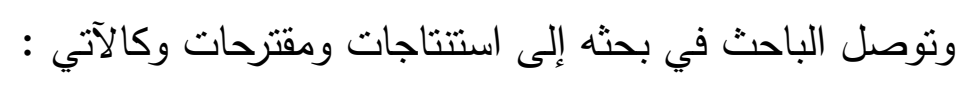

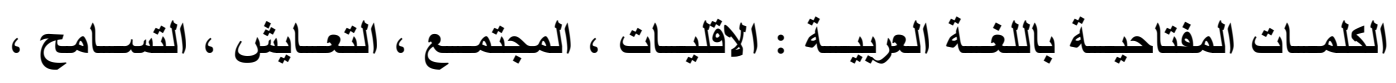

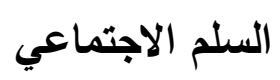

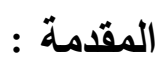

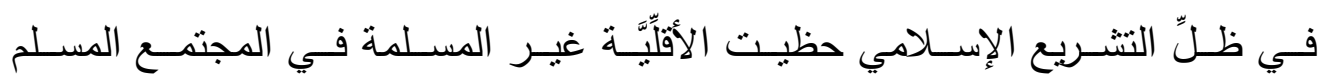

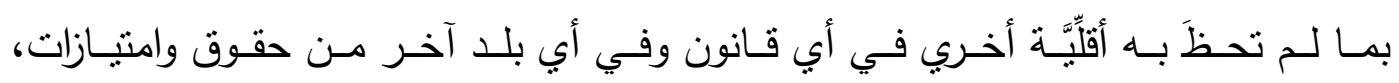

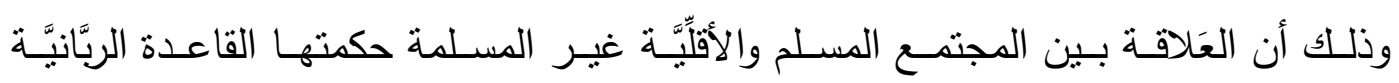

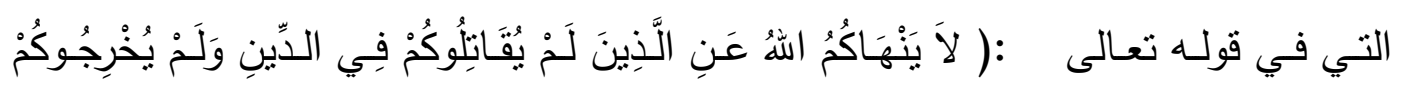

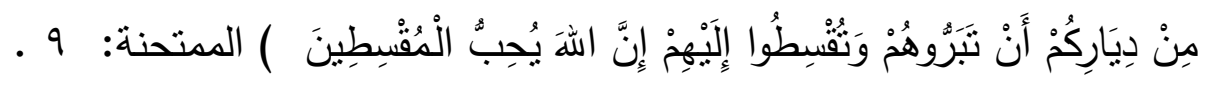




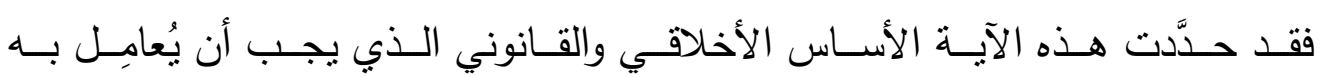

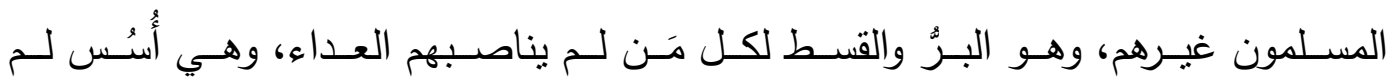
تعرفهـا البشـربَّة قبـل الإسـلام، وقـد عاشــت قرونَّا بعـده وهـي تقاسـي الوبـل مـن فقدانها، ولا تزال إلـي اليـوم تتطلَّع إلـي تحقيقهـا في المجتمعـات الحديثـة فـلا تكـاد تصـل إليهـا، بسبب الهوي والعصبيَّة والعنصريَّة.

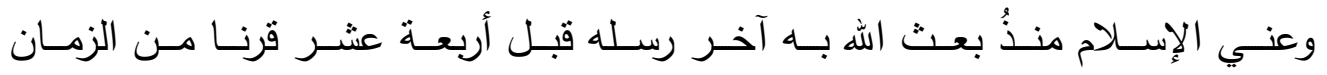
بحقـوق الإنسـان، كـل إنسـان، مـن أي جـنس كـان، ومـن أي ديـن كـان، ومـن أبي إقلـيم كان، وذلك بنـاء على فلسـفته في تكريم الإنسـان مـن حيـث هـو إنسـان، اسـتخلفه الله في الأرض، وسـخر لـه مـا في السـموات ومـا في الأرض جميعـا منـه، وأسـبخ عليـه

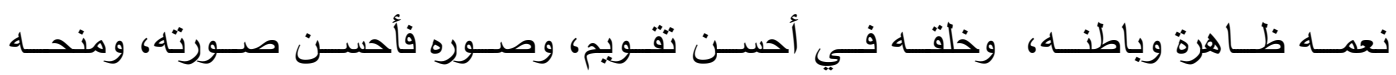

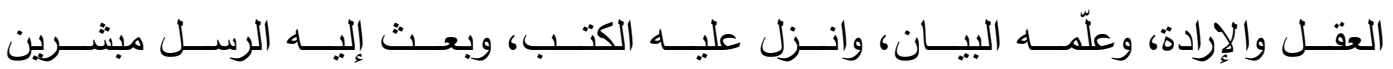
ومنذرين، ليهدوه إلي صراط ربه العزيز الحميد. وفي وقتتـا الحـالي فـانَّ هنـاك الكثيـر مـن النصـوص والدسـاتير والقـوانين والمواثيـق التـي تتـادي بحقـوق الاقليـات والاثتيـات والتعدديــة الدينيـة والقوميـة إذْ يثـبر الاعــان الـدولي حـول الاقليـات الأثتيـة والقوميـة والدينيـة الـذي صـدر عـام r99 19 عـن المنظمـة الدوليـة إلـى ضــرورة احتـرام جميـع الاقليـات الأثثيـة والدينيـة والقوميـة وغيرهــا ، دون اي تمييـز بسـبب العـرق أو الجـس أو اللغــة أو الــدين ، وأثنـار هـذا الإعـلان إلـى المـادة مـ TV العهـد الـدولي الخـاص بـالحقوق المدنيـة والسياسـية إلى ضــرورة تعزيـز وحمايـة

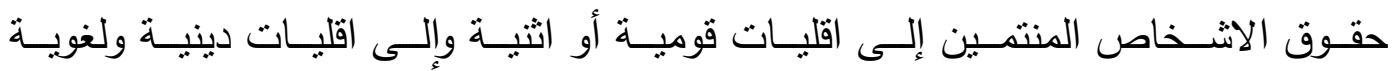
الأمـر الـذي بسـهم إلـى اسـتقرار المجتمـع وان الاقليـات جـزء مـن عمليـة التتميـة داخـل اطار ديمقراطي يستتد إلى حكن القانون •

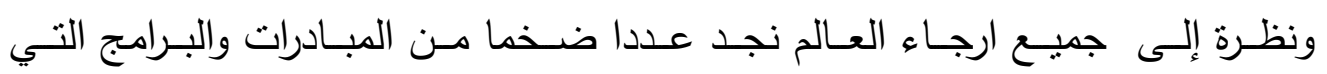

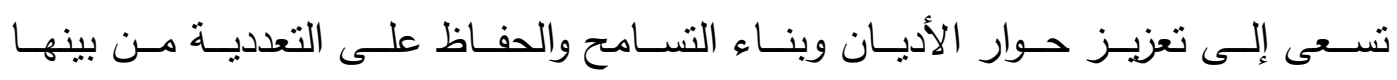
اعـلان مـراكث وقـانون حربـة المعتقد في المانيـا ومنتـدى الاقليـات في الأمــم المتحـدة

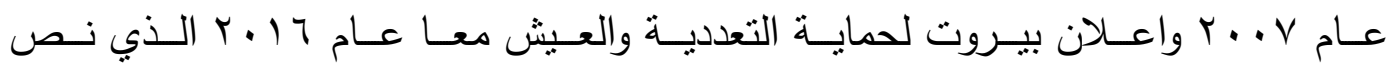
على ان التعددية سمد تكوينية لمجتمعاتتا ونعمة ووجوب حمايتها والعيش المشترك. وفـي هـذا البحـث تطرقتـا إلى المجتمـع الاســلامي هـذا المجتمـع الـذي يقـوم على

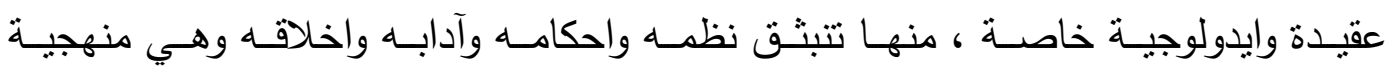
الاســلام فاتخـذه منهجــا للحيـاة ودسـتورا للحكم ومصـدرا للتشـريع والتوجيـه في كل شـؤون حياتـه وعلاقاتـه ، وكيـف يعـيش الاقليـات غيـر المسـلمة داخـل هــذا المجتمـع بـروح 


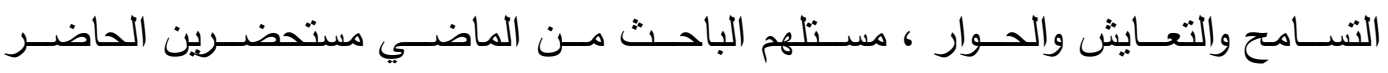
ومستشـرفين بالمستقبل وكيف تمحسورت منهجيـة الرسـول في السـلم الاجتمـاعي مبـرزين

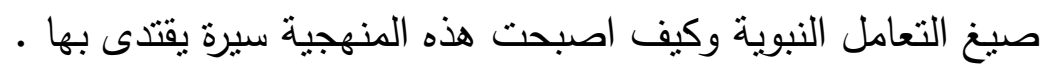
وقد تكون البحث من محاور عدة رئيسة وهي : ا ـ. الإطار العام للبحث والدفاهيم الأساسية r. المجتمع المسلم .. والأقليات غير المسلمة مقاربة منهجية الإنية

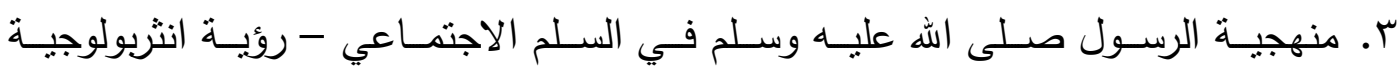
تحليلية

ـ. استتاجات سوسيولوجية ومقترحات المحور الأول : الإطار العام للبحث

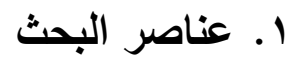

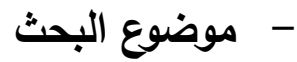

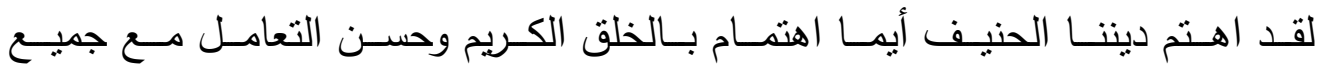

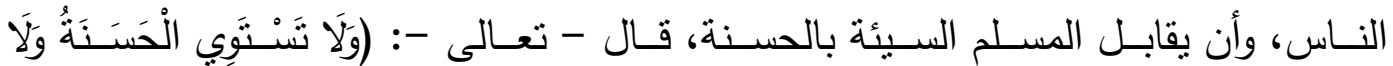

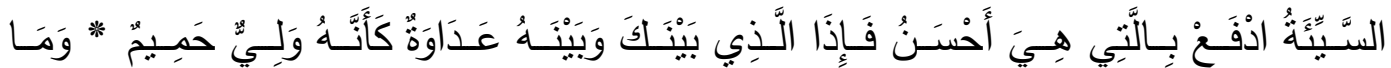

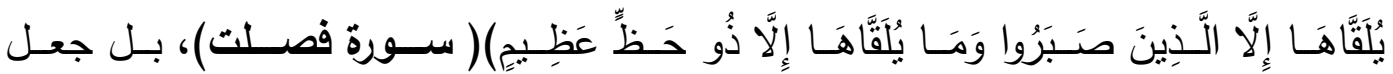

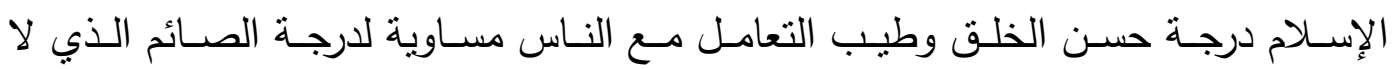

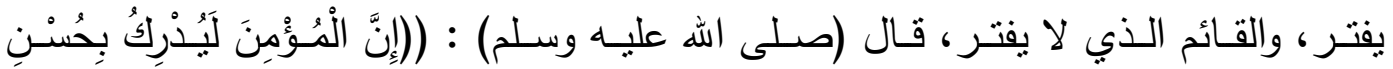

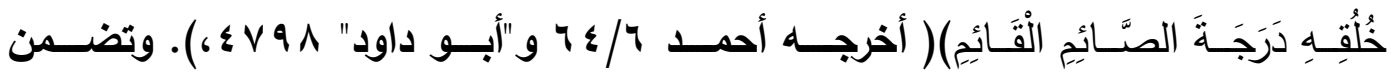
البحث اجابة عن التساوَلات الآتية :

هاهي سمات المجتمع المسلم وما هي الكيفية التي يتعامل بها مع الاقليات غير المسلمة؟

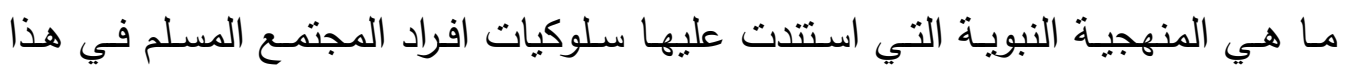

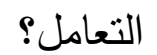

ما هي آليات واسس السلم الاجتماعي في المجتمع الاسلامي وما هي النماذج التطبيقية؟

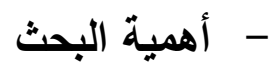
يمكن تجسيد أهمية البحث في النقاط الأتية:

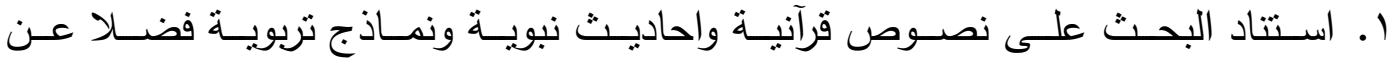
المواثيق والدساتير والقوانين التي تدعو إلى احترام التعددية الدينية . 
r. أهميـة ترسيخ مبـدا احترام الاقليـات غير المسلمة في الوقت الحاضـر كونـه السبيل

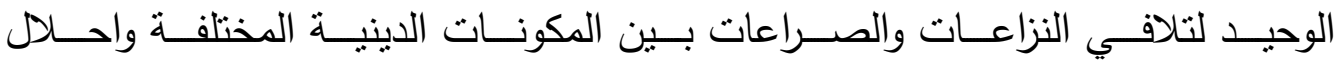

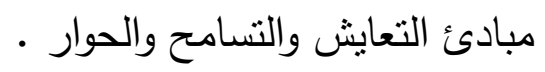

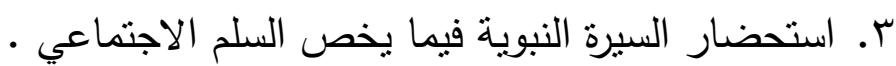

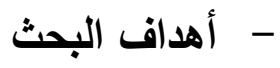

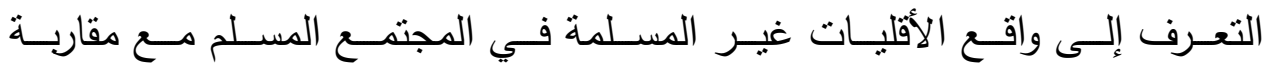

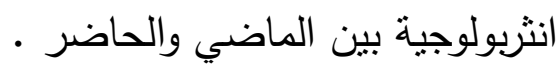

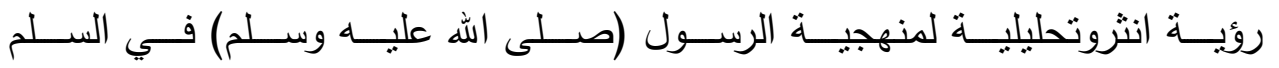

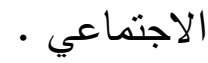

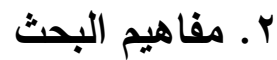
الأقلّات

ذهب الباحثن والفقهاء مذاهب شتى في تعريف للأقليات فقد عرفه قسم منهم إلى انه

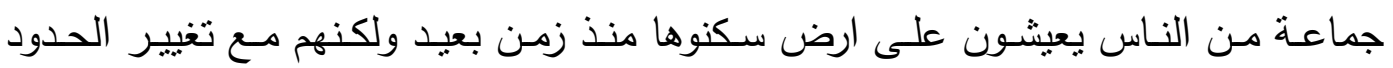

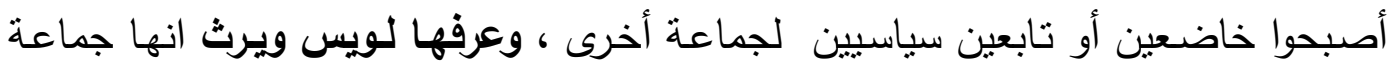

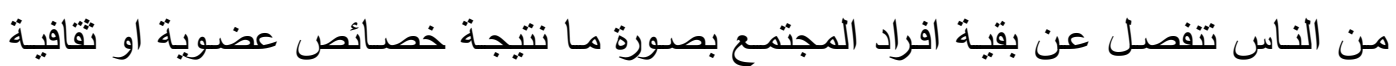

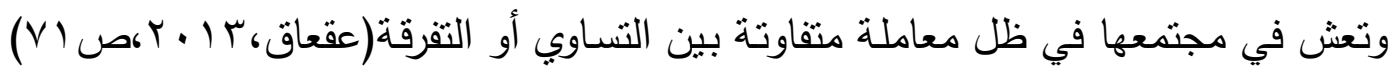
وعرفتها الدكتورة نيفين مسعد انها جماعة تشترك في احد أو أكثر من المقومات الثقافية أو فئه

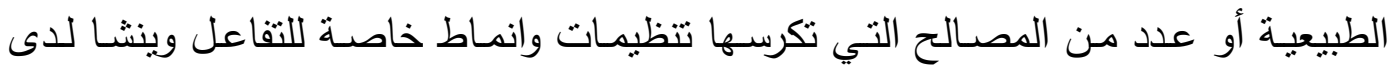

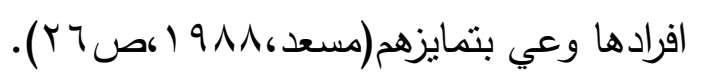

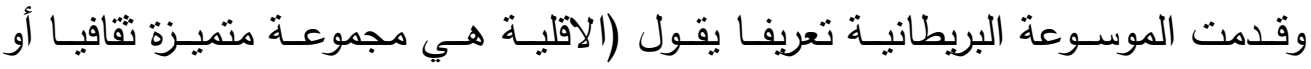

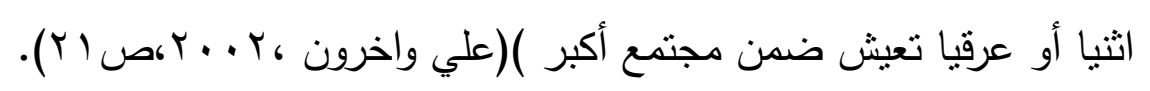

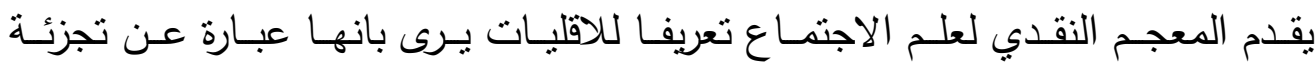

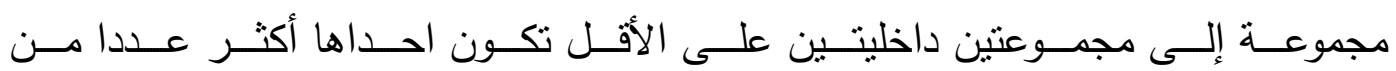

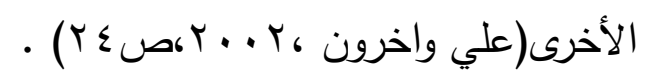
ومسن خـلال هـــه التعـاريف السـابقة يمكـن النظــر إلــى الاقليـات مـن خــله

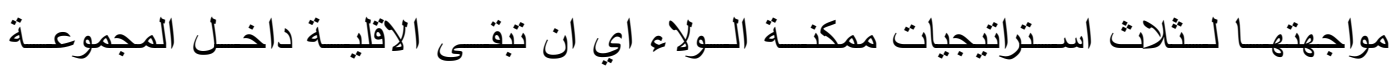

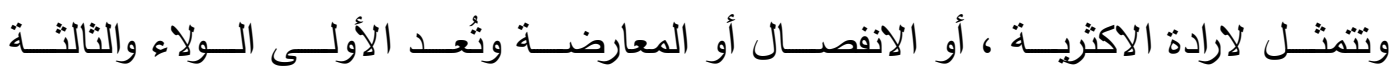

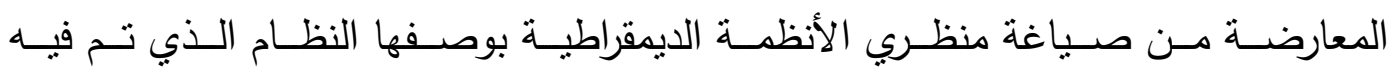

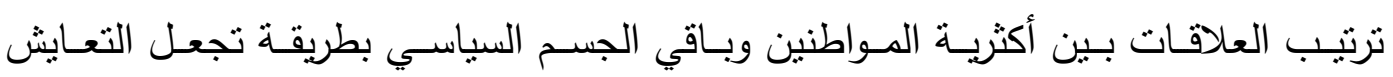
السلمي بينهم ممكنا. 
وتعـرف الاقليـة بـالمعنى الثـامل بانهـا مجموعـة انسـانية تتضـوي ضــمن مجموعـة

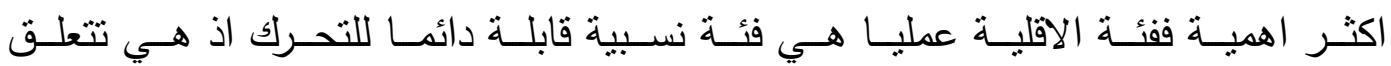

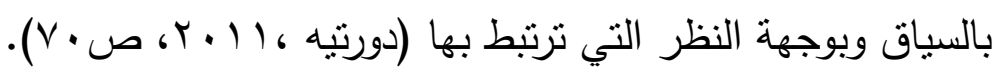

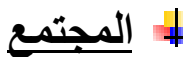

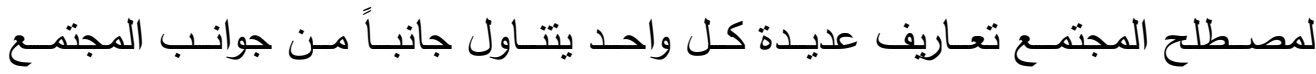

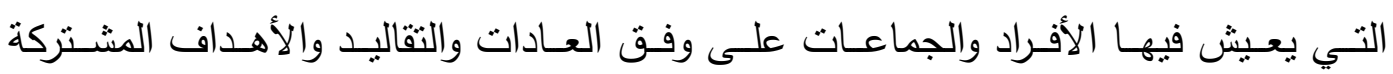
التي يؤمن بها أفراد ذلك المجتمع.

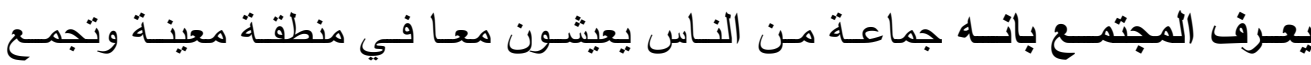

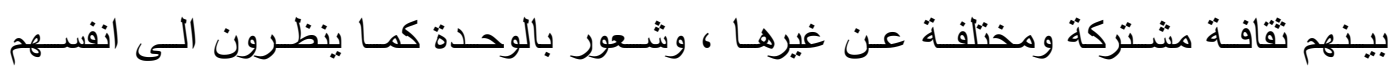

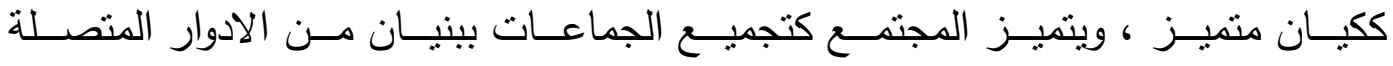

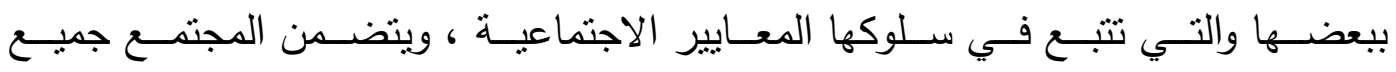

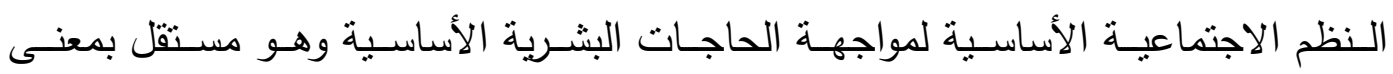

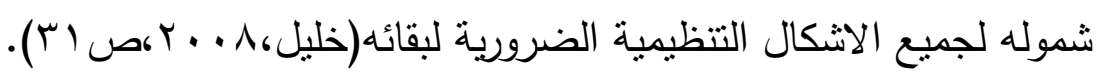

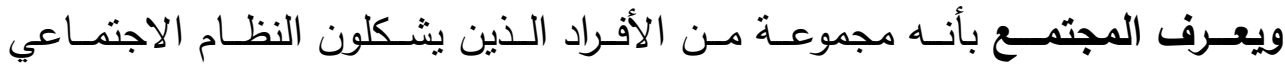

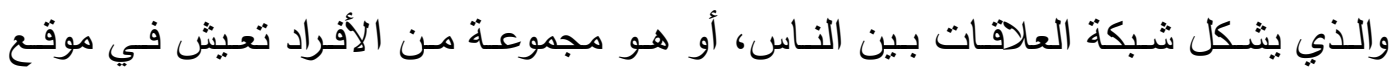

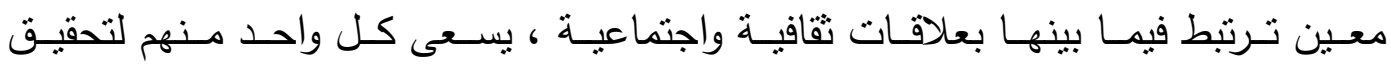

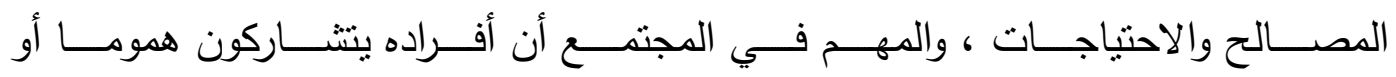

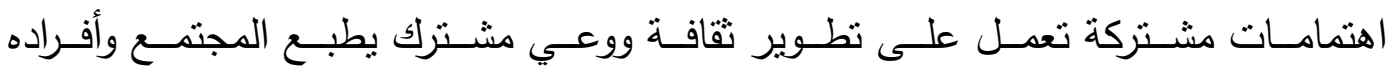

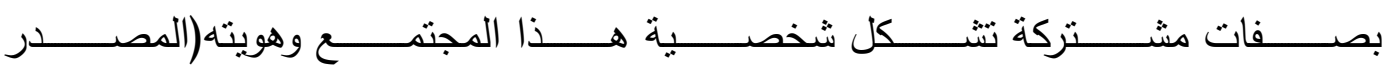

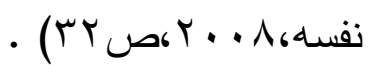

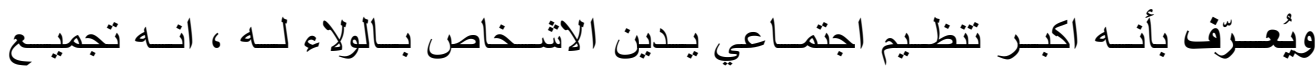

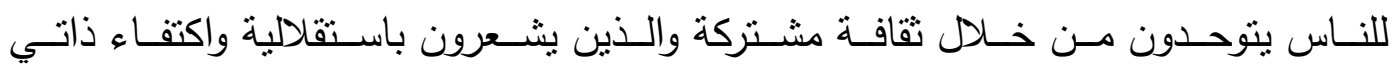

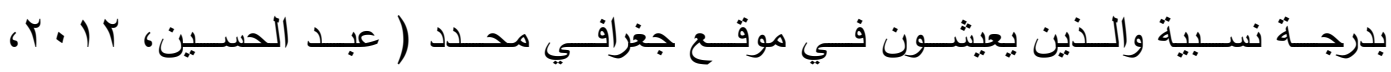
(IV)

وهنـاك مـن عـرّف المجتمـع على أنـه جماعـة مـن النـاس يعيشـون معـا في منطقة

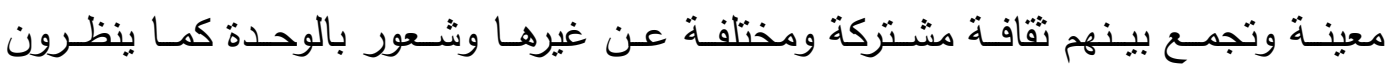

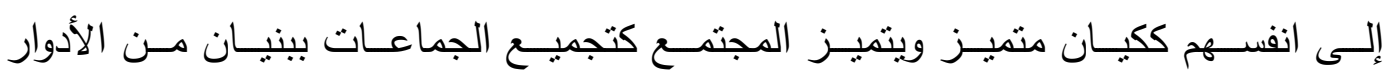

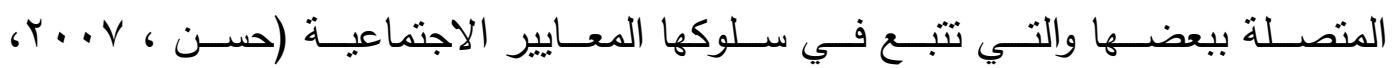


| المجتمع المسلد

المجتمـع الإسـلامي أو المجتمـع المسـلم، هـو الـذي تتمثنل فيـهـ كلمـة "لا إلـه إلا الله

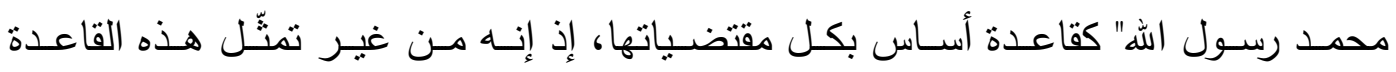
ومقتضـياتها فيـه، لا يكـون مسـلمًا، وبنـاء على ذلـك فـان هـذه القاعـدة تصـبح المرتكـز الأساسـي لمـنهج كامـل تقوم عليـه حيـاة الأمـة المسـلمة بحذافيره، فـلا تقوم هـذه الحيـاة

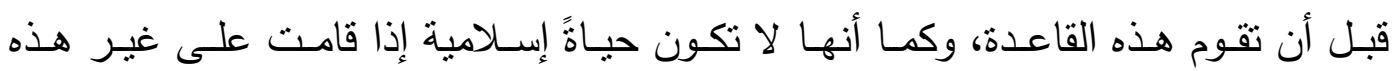
القاعدة، أو قامت على قاعدة أخرى معها. والمجتمع المسلم هو ذالك المجتمع الذي تميز عن المجتمعات الأخرى بنظمه الخاصة، وقوانينه القرآنيـة وأفراده الذين بشتركون في عقيدة واحدة، ويتوجهون إلى قبلة واحدة، ولهذا المجتمع وإن تكون من أقوام متعددة، وألسنة متباينـة خصـائص مشتركة، وأعراف عامـة،

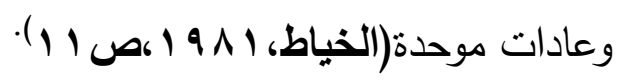
ومن خلال هذا التعاريف يتضح لنا أن المجتمع الإسلامي مجتمع رباني، حددت أهدافه ورسمت ملامحه ، واستمد تتظيمه من نصوص الثربعة الإسـلامية السمحة وأحكامها، التي

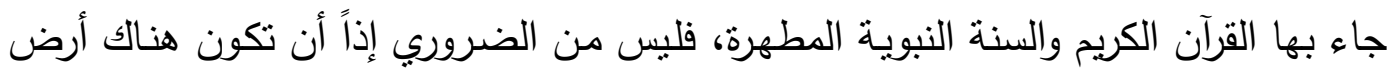
معينـة لهذا المجتمع، وليس من الضـروري أن يعيش أفراده معـاً لمدة طويلـة، وأهدافهم ومصـالحهم ليسـت مشـتركة، بـل هـي واحدة، يحترمسون العـرف والتقليد والقيم الاجتماعيـة وبضعون الوحي والسنة والاجتهاد واحكام الدين ليرتبوا نظامهم الاجتماعي. \# السلم الاجتماعي الســلم كلمــة واضـــة المعنـى، تعبـر عـن ميـل فطـري في أعمـاق كل إنســان،

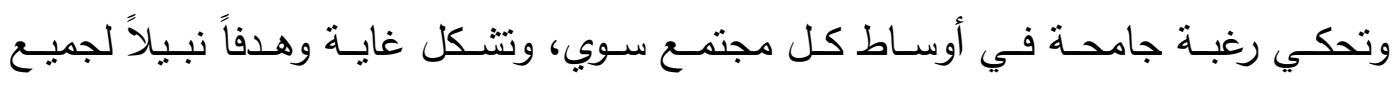

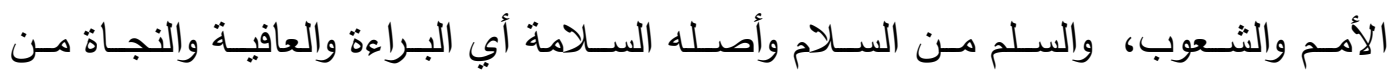

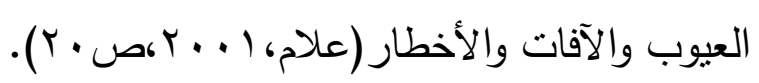

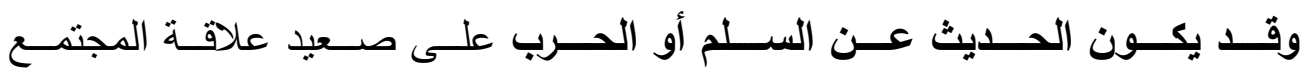
بمجتمعـات أخـرى، أو يكـون على مسـتوى الوضـع الـداخلي للمجتمـع والعلاقـات القائمـة

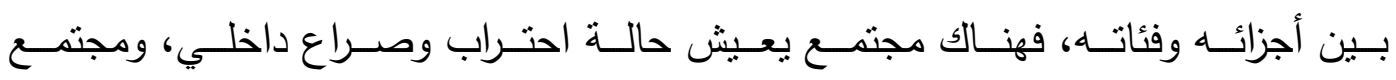
تسوده أجواء الوئام والانسجام والوفاق.

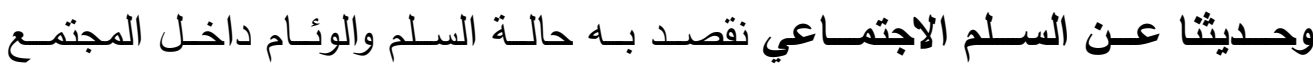

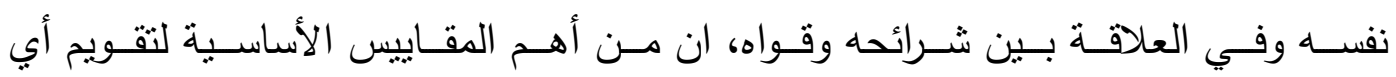

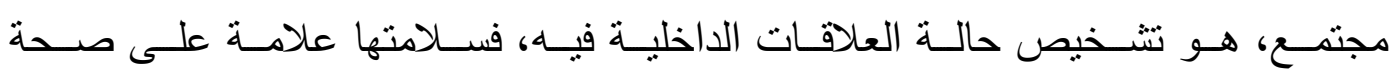
المجتمع وامكانية نهوضه، بينما اهتراؤها دلالة سوء(علام، ( . . ب،صع ؟) . 
ان السلم يعبر عن عملية اجتماعية ثقافية لها العديد من المستويات ، والتي تتضمن السلم على المستوى العـائلي وعلى مستوى المجتمـع ، ثم على المستوى الإقليمي والدولي أيضـا كما يتضـن السلم الداخلي كذلك ، أي السلم مـع النفس ، وهو هذا النوع من السلم الضروري من أجل خلق عالم سلمي ، وهو يعني أيضـا استبعاد كل مظاهر العنف والقهر

والخوف في المجتمع(Unesco,1995,p.3) •

ومــن ثـــ يُعـــ الســلم الاجتمــاعي مبـدأ للتعـايش ولاحتـرام الآخـر ، وهـــا بعنـي

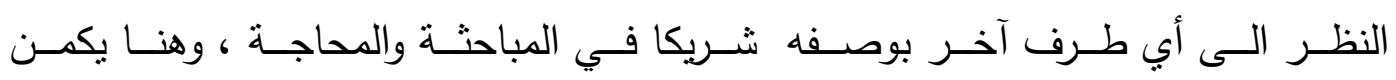

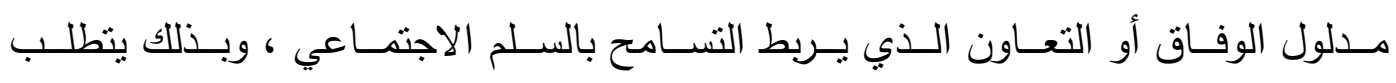

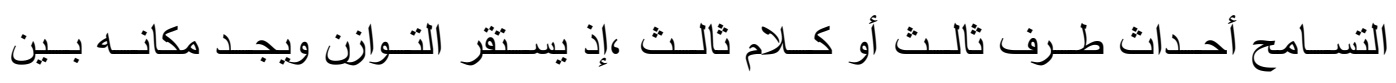
الأنانيات الفردية، والجماعية والعشائربة(الخطيبي،9999 (،ص99).

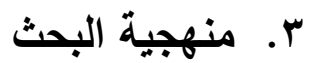

- المنهج التاريخي : يعتمد هذا المنهج على ثتبع الظاهرة المراد دراستها عبر المراحل التي مرت بها، ومـا طرأ عليها من تغييرات وتطورات، كمـا أنّ هذا المنهج لا يعتمد فقط على لهى تدوين الأحداث والوقائع التي حصلت في الماضـي، وإنّــا يعمل على دراستها وتحليلها وتفسيرها على أسس وقواعد علميـة مدروسـة، بهدف الوصـول إلى التعميمات التي تشـاعد

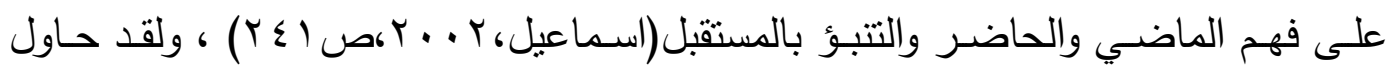
الباحث اسـتعمال هذا المــهج لأجل تعقب جذور العلاقـة التي قامـت بـين الذات العربيـة الإسلامية ولاسيما منذُ تشكلها في ظل الدين الإسلامي وبين الآخر ، وذلك عبر الوقوف عند مراحل تكون هذه العلاقة فضلاً عن معرفة أنماط أو أثكال هذه العلاقة التي قامت بينهما، والعوامل أو القوى الاجتماعية - التاريخية عبر العصور التي أسهمت في تكوين هذه العلاقة بينهما وتحديد وجهتها أو أنماطها المتبدلة من حين إلى آخر . - المنهج الانثريولوجي : يعرف المنهج الانثروبولوجي بشكل عام على أنه علم الإنسان وهو العلم الذي يسـى لدراسـة مجرى التطور الإنسـاني من الناحيتين البيولوجيـة والتقافية والقوانين والمبادئ التي تحكم هذا التطور والارتباطات التي بين الجوانب الطبيعية المختلفة للإنسان وبين عادات الثـوب في الماضـي والحاضر والانماط التي تميز مجتمعات معينة دون غيرها

أما التعريف العلمي للمنهج الأنثروبولوجي فيعرف بأنه، هو منهج شامل لدراسة الإنسان ولا يكتفي بدراسة ناحية واحدة أو مظهر واحد من مظاهر حياته المعقدة أو يقصر اهتمامه على دراسة تكوينه الفيزيقي فقط وإنما يحيط بكل خصائصه ومقوماته البيولوجية والاجتماعية والثقافية سواء في الماضـي البعيد أو الماضـي القربب أو الحاضر ، إن من سمات هذا 
المنهج قدرته على الولوج داخل المجتمعات ودراسة بعض الظواهر الإنسانية أو الاجتماعية

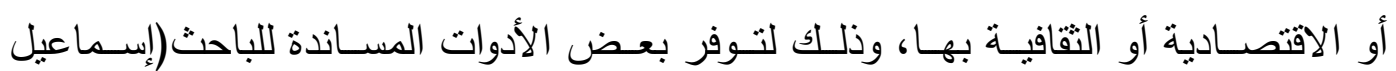

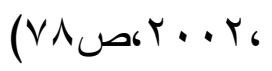

وباسـتعمال الباحث للأسـلوب الاسـتقرائي افــاد مـن هـذا المـنهج لقـراءة المجتمعـات

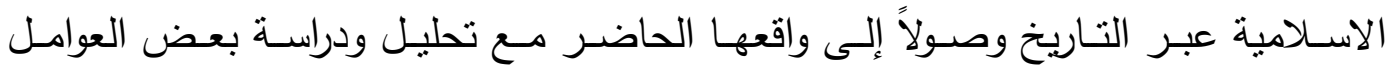

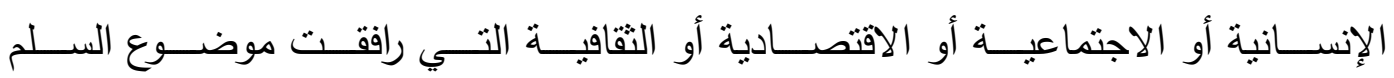

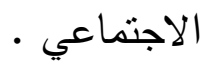

المحور الثاني: المجتمع المسلم .. والأقليات غير المسلمة مقارية منهجية التعـديات الانسـانية ظـاهرة اجتماعيـة طبيعيـة ، وتمثـل لونــا مـن ألـوان الأبـداع

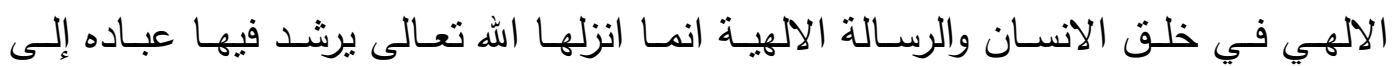

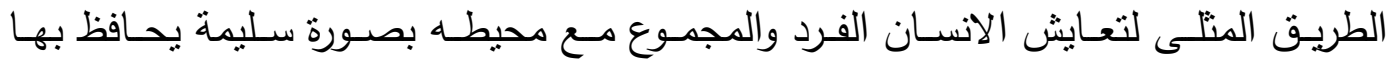
على نوعـه الانسـاني ويحـافظ عـل مــا حولـه مـن مقدرات الطبيعـة التـي سـخرها الله

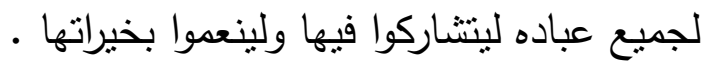

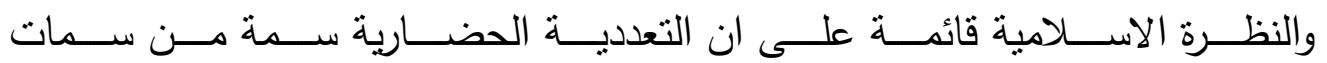

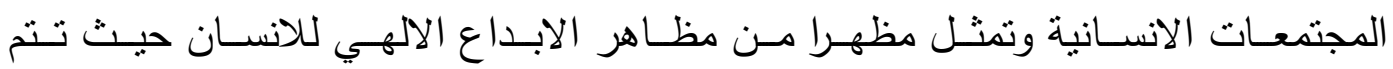

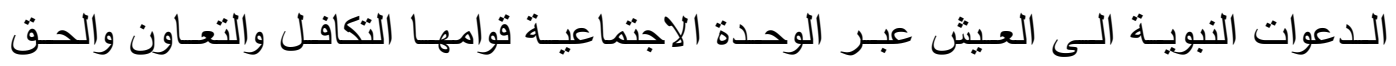

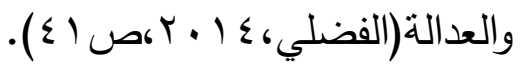

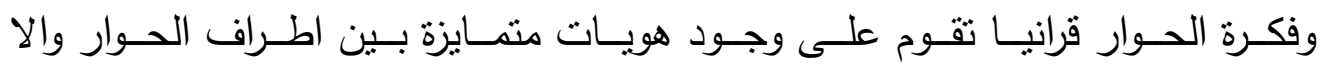

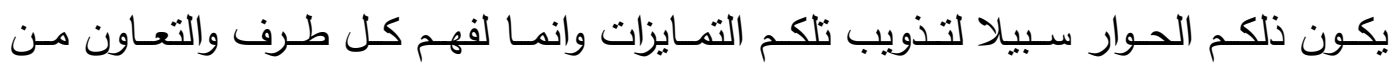

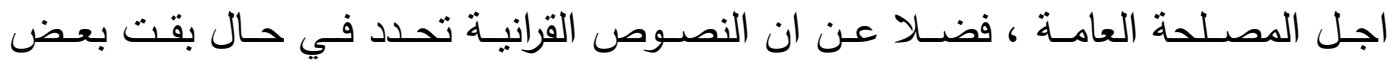

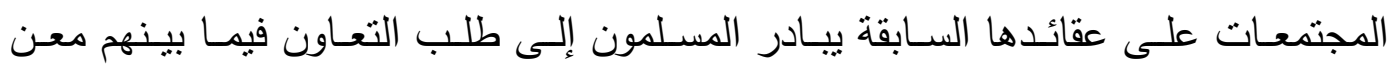

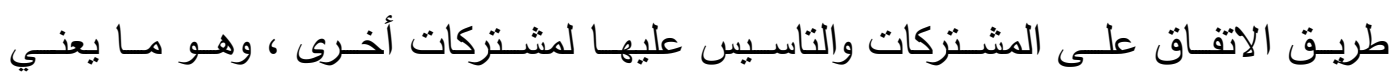

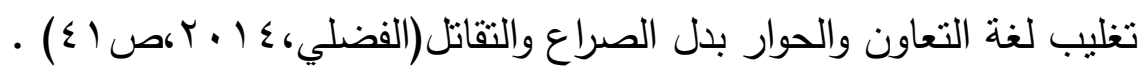
سيتضمن هذا المحور النقاط التالية :

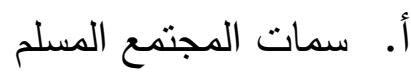
ب. الاقليات غير المسلمة ... مقاربة الثوغرافية

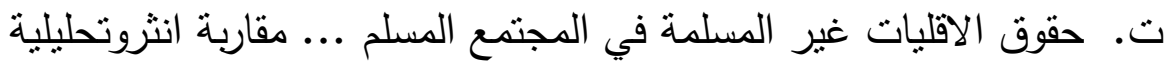
ث. المنظومة الدينية وبناء العلاقات الانسانية ... رووية انثربولوجية النية 
أ. سمات المجتمع المسلم

إن المتمع الإسـلامي يتميز عن غيره من المجتمعات بعدد من السمات جعلته بحق

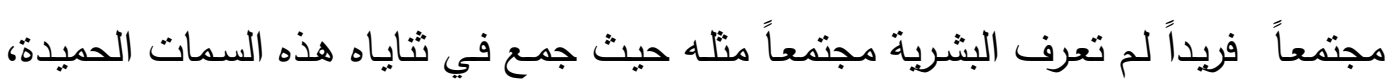
ليكون أنموذجاً يرتجى، ومثنالاً يحتذى عند العقلاء من بنـي البشر، إذْ إنَّ الطابع المميّز للمجتمع المسلم، هو أنـه مجتمـع مترابط، متضـامن، متماسك، تتضبط مسبرةُ حياتِه بأحكام الثربعة الإسـامية، وتصلح أحواله بانتهاجه لمسلكها القويم، قد صِيغت شخصيتُه بالتربية الإسـامية، فانطبعت بخصـائص هذه التربيـة، وبـالمنهج الثابـت الراسـخ الذي هو القاعدةُ

الذهبيةُ للمجتمع المسلم الذي تصوغه التعاليم الإسلامية ، وقد امتاز بالسمات الأتبة:

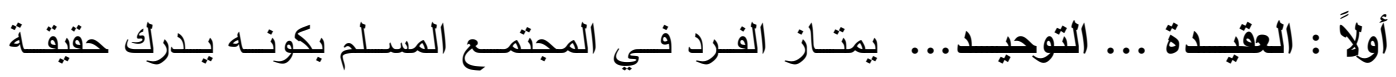
الالـه المعبـود وحقيقـة الكـون الــي يعيش فيـه وحقيقـة الحيـاة التي ينتسـب اليهـا وحقيقـة

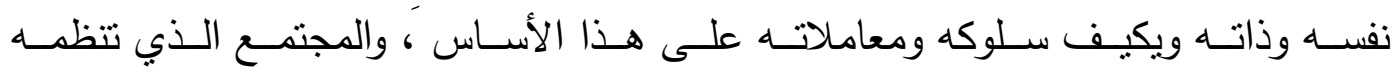

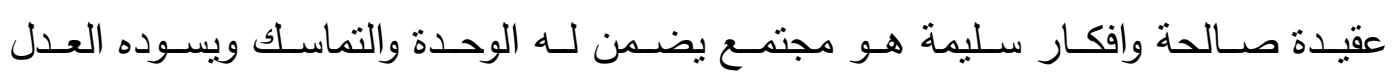

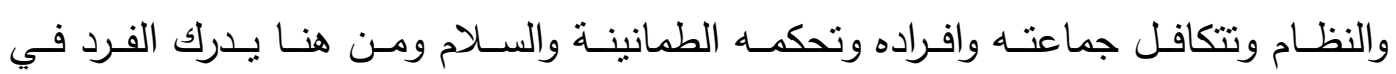

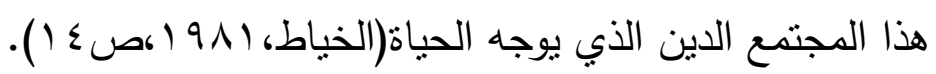
ثانياُ: الأُخوة الإنسانية... للأخوة في المجتمع الإسـلامي مرتبـة عالية لما لها من اثر بالغ في بناء هذا المجتمع الذي يدعو إليه الإسـلام ببناء العلاقة الوثيقة بين أفراد المجتمع فقال

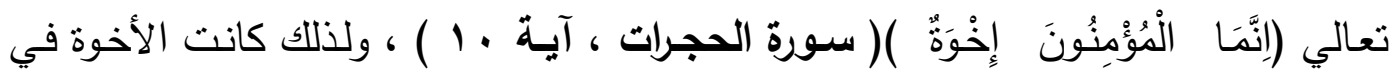
الإسلام ذات شأن كبير عمل الرسول الكريم صلي الله عليه وسلم علي بنائها منذ اللحظة الأولى التي دخل بها المدينة المنورة إذ قام صلى الله عليه وسلم بالمؤاخاة بين المهاجرين والأنصار ولقد فهم الصحابة الدرس جيدا من الرسول الكريم فقاسموا المهاجرين أموالهم بهر

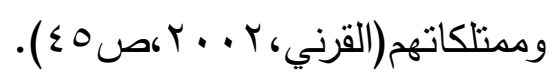

وقد عمل النبي الكريم صلي الله عليه وسلم علي مد جذور الأخوة بين شرائح المجتمع كافة فنشر الاخوة وافشاءها بين الناس هو في الحقيقة ارساء لدعائم مجتمع متحاب متكافل يرتبط الناس فيه بأواصر قوية تشد بعضهم بعضا ، وهكذا يعمل الإسلام بشربعته السمحة

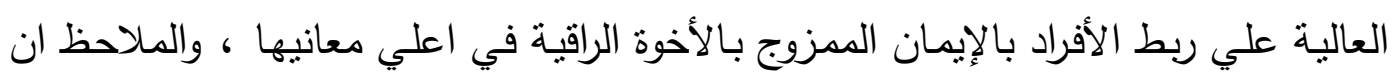
المجتمع الذي يفقد الأخوة يبدأ بالانهيـار والتفكلك لأنـهـ يفقد المحبـة ويفقد التسـامح والتواد

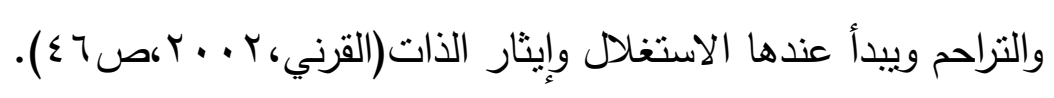
ثالثاً : العدالة في التعامل ... الباحثون في القانون عرفوا العدالة بأنها: (القواعد القائمة إلى جانب قواعد القانون الأصلي مؤسسة على وحي العقل والنظر السليم وروح العدل الطبيعي بين الناس) والثرائع القديمة استقت مبادئ العدالة من هذا المصدر الذي هو العقل وشعور 
العدل في النفس ، ولكن هذا المصدر اتخذ صوراً مختلفة تبعاً لاختلاف الثـوب، فكان مصدر العدالة عند الرومان (قانون الثعوب)، وعند اليونان (قانون الطبيعة)، وعند الإنكليز

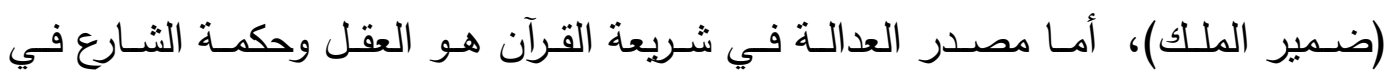

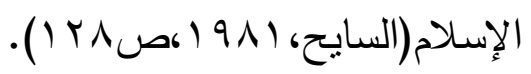

والعدل في الاسـلام لا يتأثر بحبّ أو بغض، فلا يفرق بين مسلم وغير مسلم، كما لا

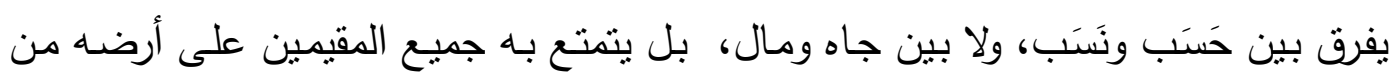
المسلمين وغير المسلمين مهما كان بين هؤلاء وأولئلك من مودة أو شنآن، بقول الله تعالى:

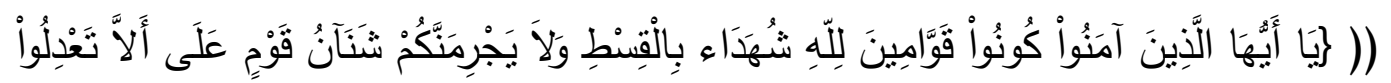

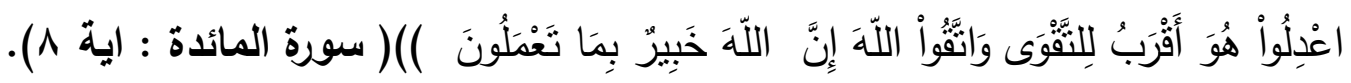
رابعاً : تكامـل الأنسـاق في المجتمـع الإسـلامي من السمات التقافية التي ميزت المجتمع الإســلامي هـو التكامـل والثـمولية فـي الوظـائف والأنسـاق وعلى اختلافهـا الاجتماعيـة

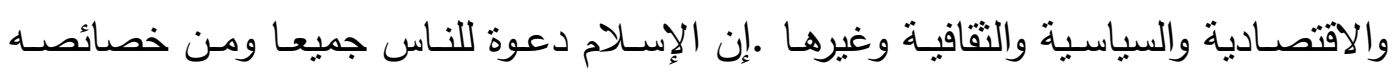
الشمولية والتأكيد على وحدة الأصل البشرى والتعايش وتحقيق المصالح البشرية، وإن موقع

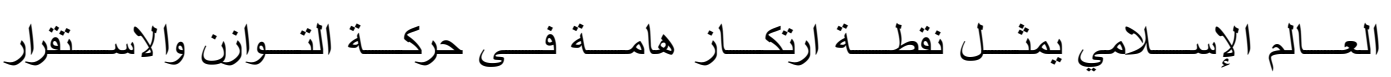

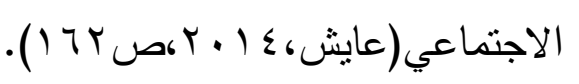

لذا لأبد أن بدرك المجتمع المسلم مع إدراك واجب التكليف الربانى لهم بوصفهم الأمة الوسط التى بوأها الله مههة الثـهود الحضـارى بين الناس، ولتحقيق هذه الغاية جاء التكامل في الأنسـاق داخل المجتمع المسـلم ليؤكد الانفتاح بكل موضـوعية وحكمـة باتجـاه ممارسـة الأدوار واحترام الوظائف لكل نسق ، وتكامل الأنساق وشموليتها في المجتمع المسلم تأني عن طريـق التحليـل الدقيق للمقومـات الثثلاث "كرامـة الإنسـان، ووطنيـة الإنسـان، وحضـارة

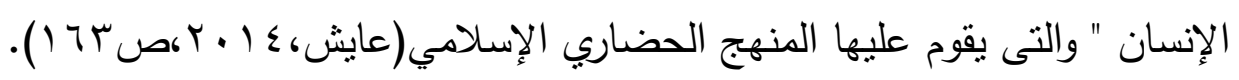

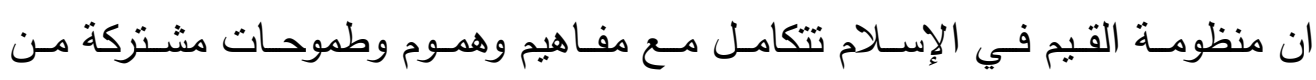

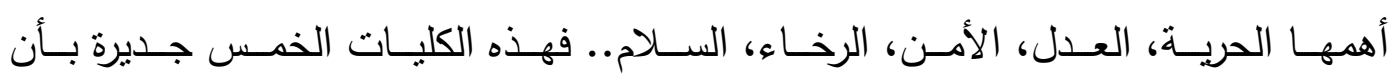
تكـون منظومــة حضـارية إنسـانية.. يتعـاون النـاس جميعـا على تحقيقهـا ومحاربـة كـلـ

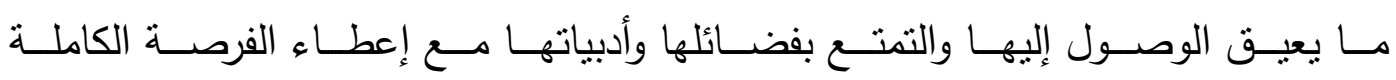

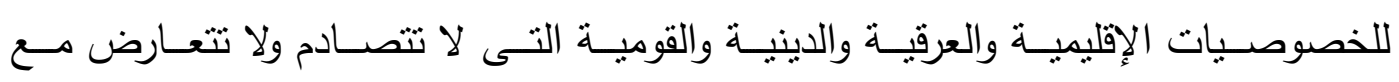

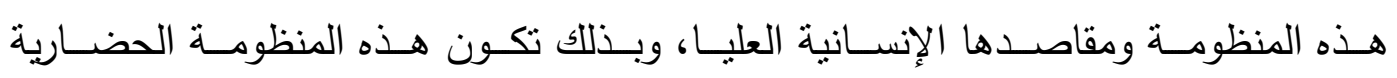

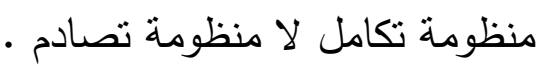


أن المنهج الحضارى الإسلامي يدعو إلى التكامل بين الحضارات على أساس من القيم

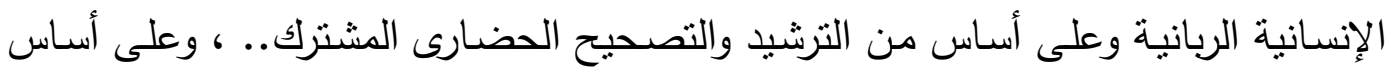
النكامل الذي يحمله المجتمـع المسـلم بين أنسـاقه ، ممـا يحقق الجانب الفاعل في تكوين المجتمع المسـلم الذي ينظر إلى الجميع نظـرة واحدة ويشـمل الجميع بأنسـاقه وخصائصسه وعناصره التي تؤكد على بناء الفرد بصورة فاعلة داخل هذا المجتمع • خامسـا : التعـايش مـع الآخـر الإسـلام ينظـر إلـى الإنسـان مـن حيـث انـه إنسـان

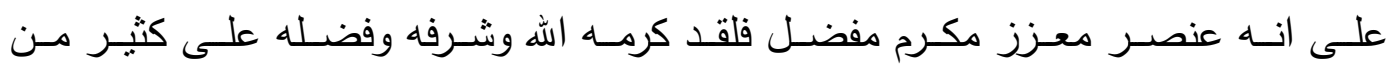

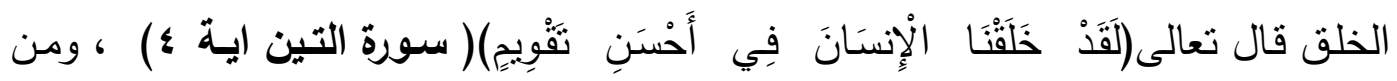
التكـريم النبـوي لجـنس الإنسـان داخـل المجتمـع الإســلامي أن النبـي صــلـى الله عليـهـ

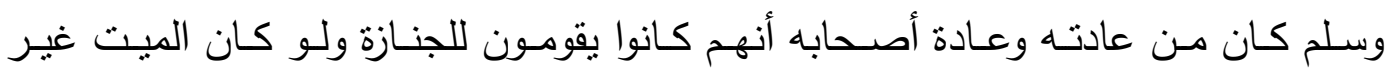

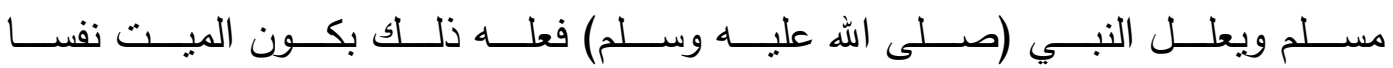
إنسانية(اليافعي، 1 1 • بكص (Y). وقـد الغـى الإســلام ضــن منظومتـه الاجتماعيـة التمبيـز بـين البثـر على أسـاس الألــوان أو اللغــات أو الأجنـاس أو الأعـراق ، فجعـل البثـر سواسـية لا يتفاضـلون إلا

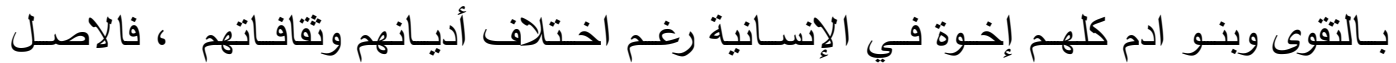
في التكريم الحرية .

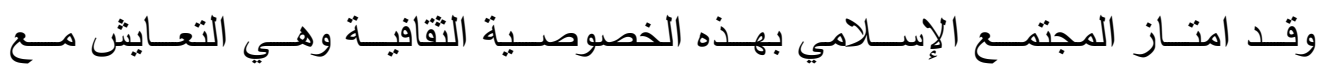

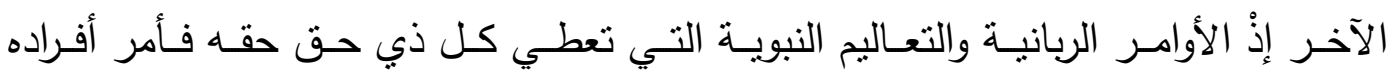
المسـلمين بواجبـات منوطـة بالطاعـة والتقوى فـأمرهم (بحسـن الجــوار وحسـن الخلـق وحسـن المعاملـة معهــم والرحمـة والثـفقة واللـين وحسـن الكــلام وعيـادة مريضـــهم

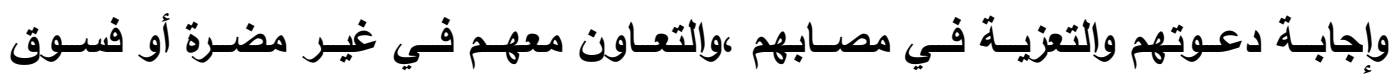
والتحيـة والسـلام علـيهم وحرمسة دمهـم ومـالهم عرضـهم كحرمسة المسـلمين) وهذا يـل

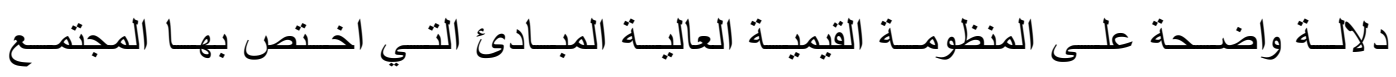
الإسلامي منظومة مميزة في مسالة التعايش وقبول الآخر ضمن هذا المجتمع •

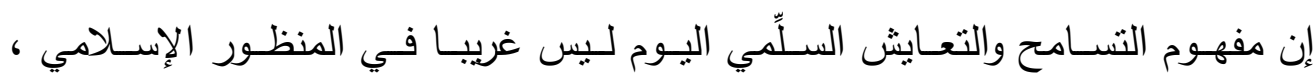

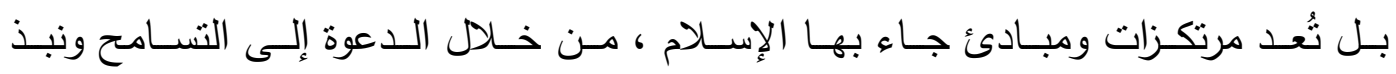

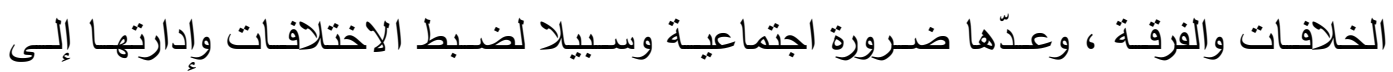

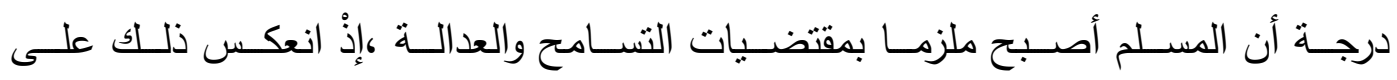

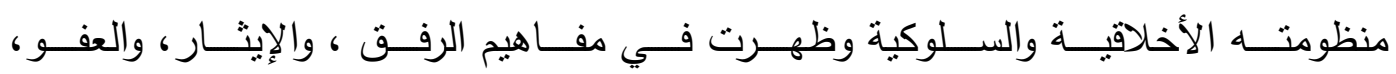


والإحسـان، والقـول الحسـن ،والألفــة والأمانــة ، ونزلــت عشـرات الآيـات القرآنــة تــــو إلى التسامح والتعايش والترابط.

ب. الاقليات غير المسلمة ... مقارية اثنوغرافية لقد احتضن المجتمع الاسلامي اعراقا وقوميات مختلفة وهي تعيش في ظل قيم واحدة

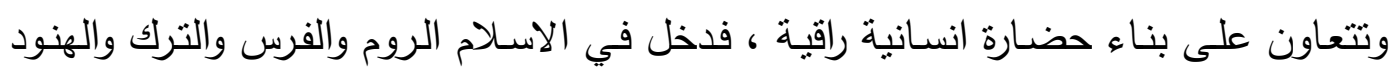

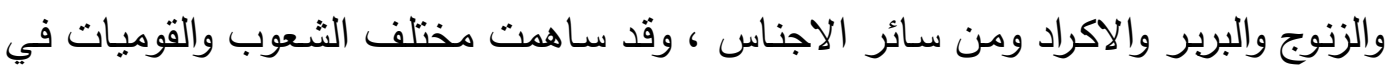

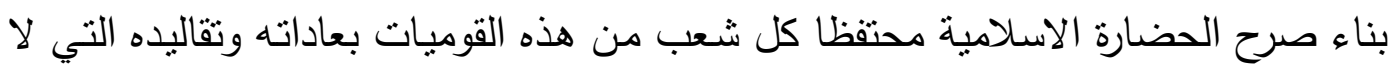

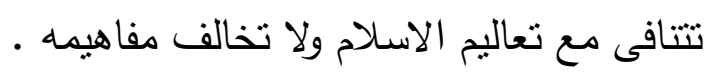

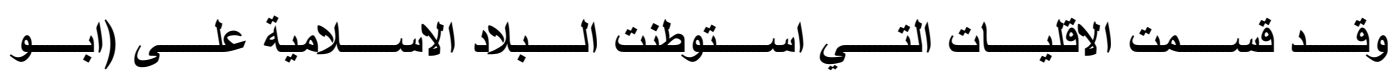

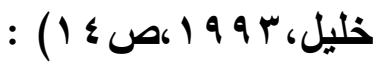

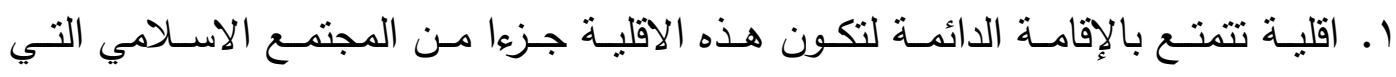

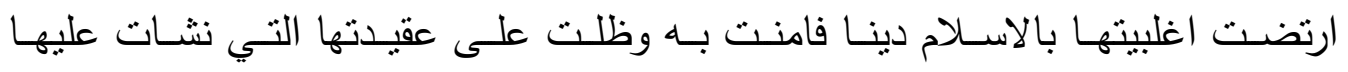

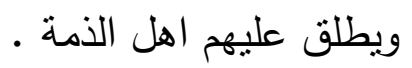

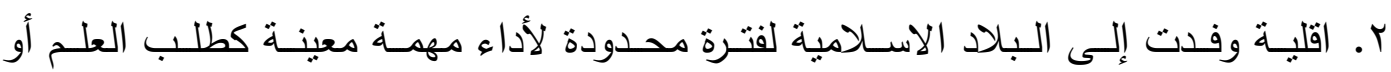

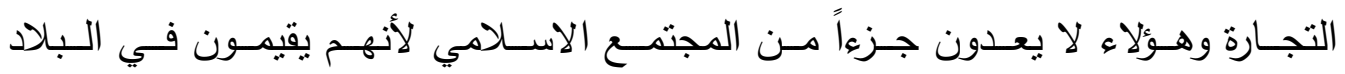

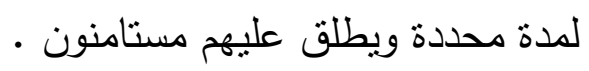

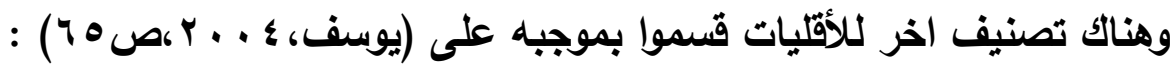

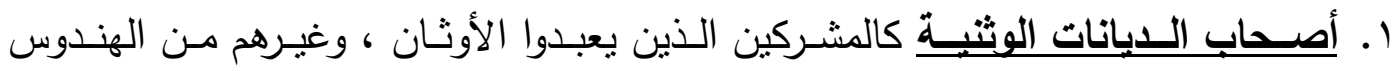
والبوذيين - البين

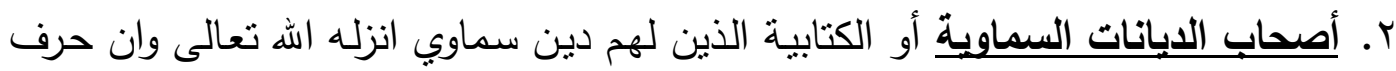

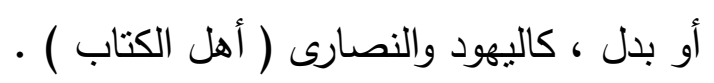

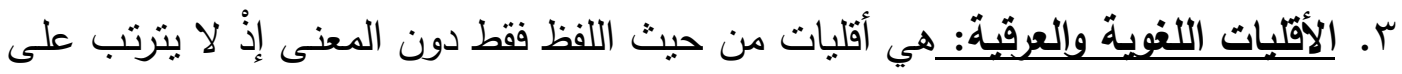

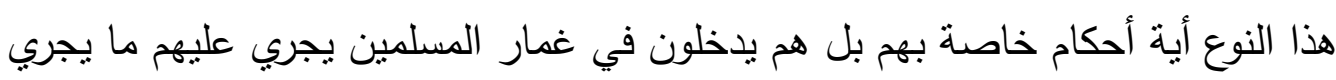

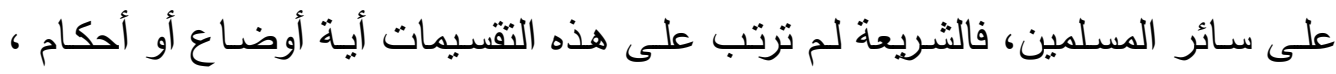

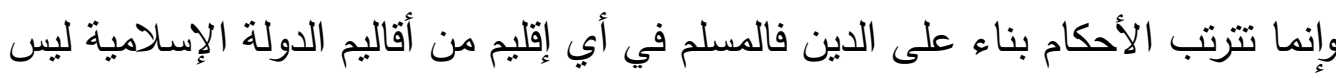

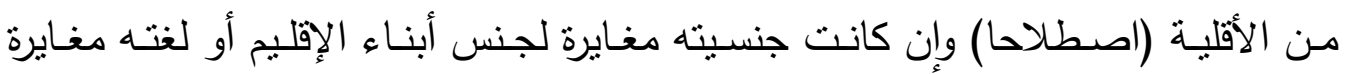

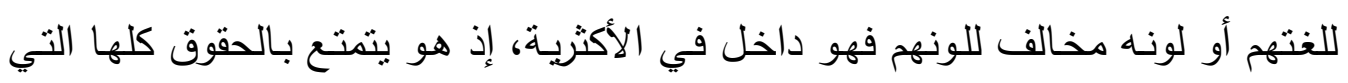

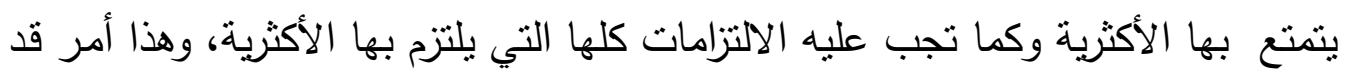
عمت به النصوص وتصرفات المسلمين في أزمنة الخلافة الراشدة . 
ت. حقوق الاقليات غير المسلمة في المجتمع المسلم ... مقاربة انثروتحليلية

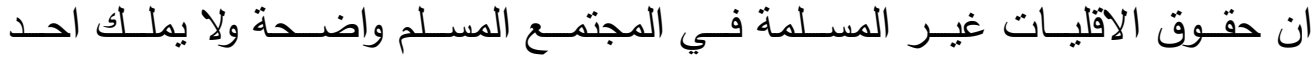

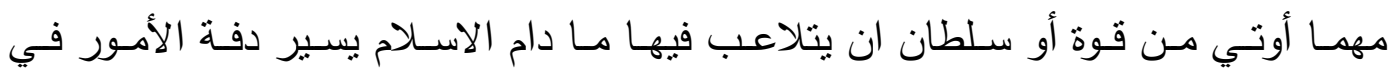

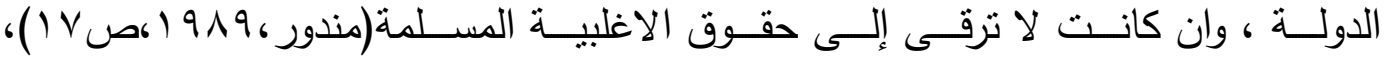

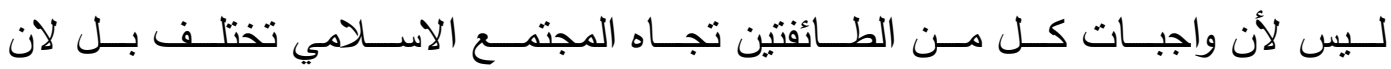

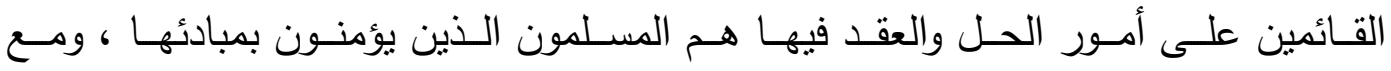

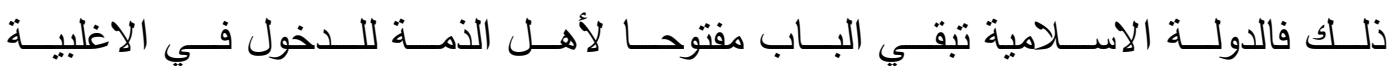
والاشتراك بإدارة الأمور أذا قبلوا بمبادئ الاسلام(مندور ،919 (،صدم ( ).

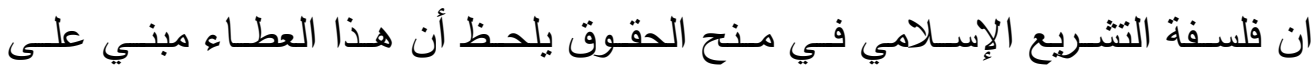

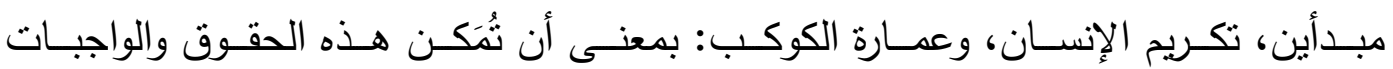
الإنســان مــن عمــارة الأرض، فتكــريم الإنســان مــن الأخلاقيــات التــي شــرعها الله

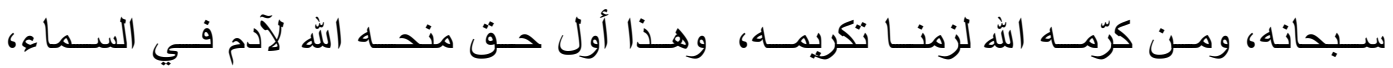
وهـذه الآيــة الكريمـة: (ولقد كرمنـا بنـي آدم) ينبغـي أن تكـون مرجعـا في تكـريم الإنسـان

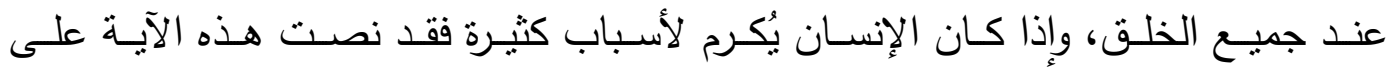

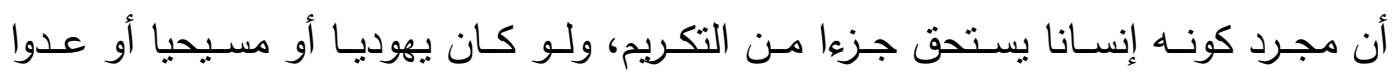

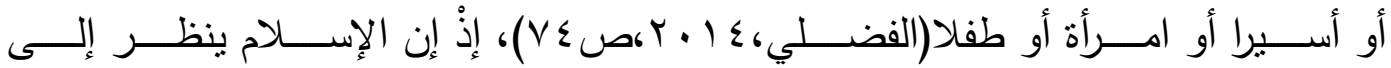

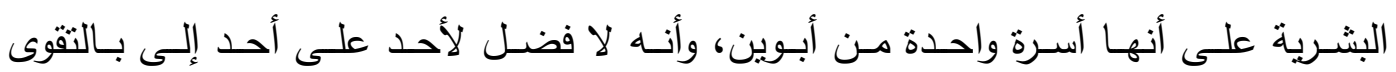

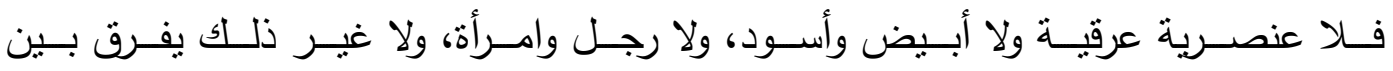

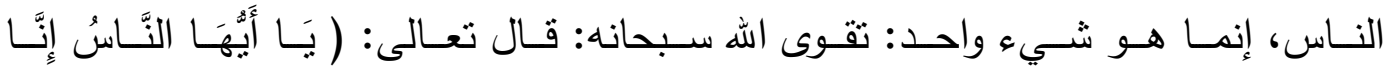

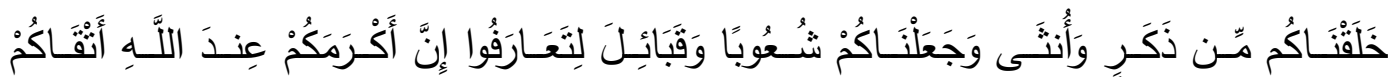

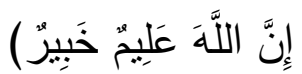

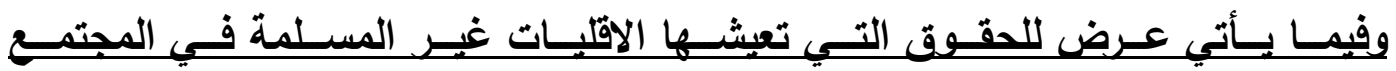
ا ـــق الحيـاة الكريمـة وحفـظ النفـوس ... قـرر الاسـلام ان البشـر كلهم مشسـاوون في اصـل خلقتم ، وان كـرامتهم كـادميين يجـب ان تصـان وتحفظظ ، لان حـق العـيش في الحيـاة منحسه لهم خـالقهم عز وجـل وهذا الحـق مشـترك بـين جميـع بنـي ادم فحرم قتـل

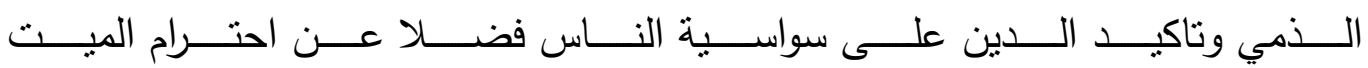

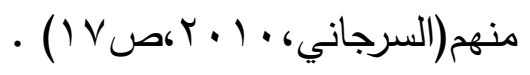




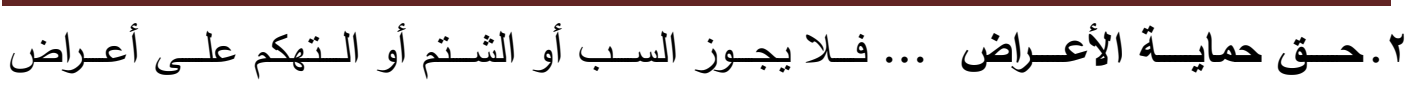

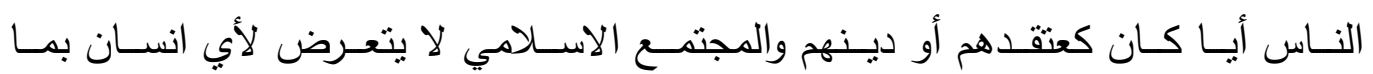

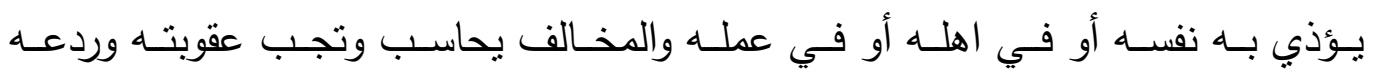

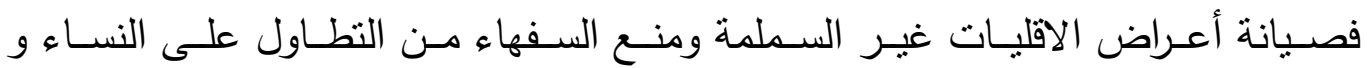

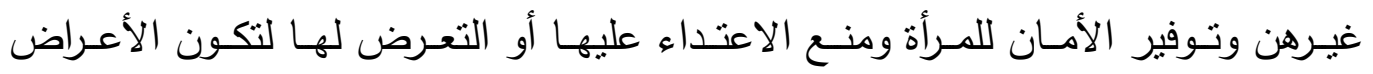

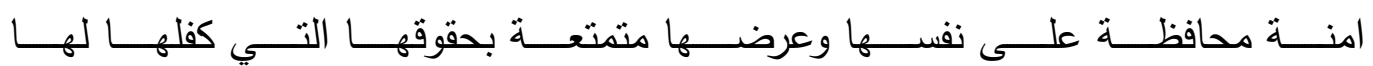

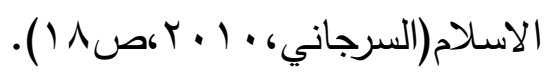

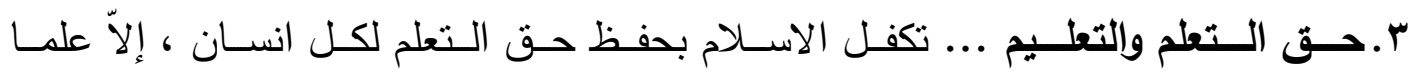

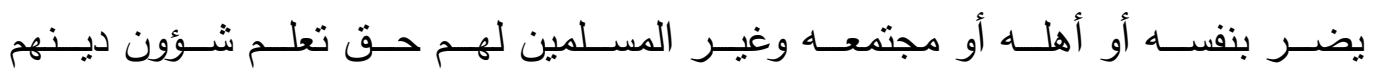

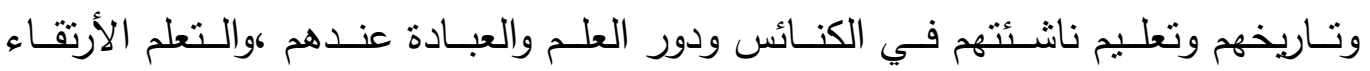

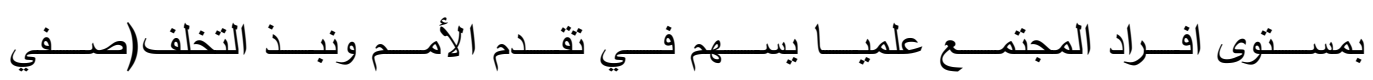

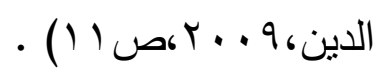

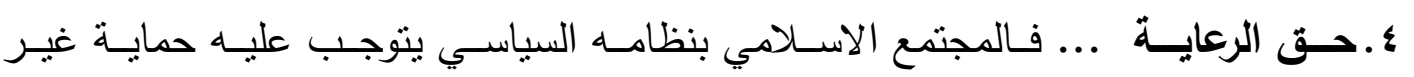

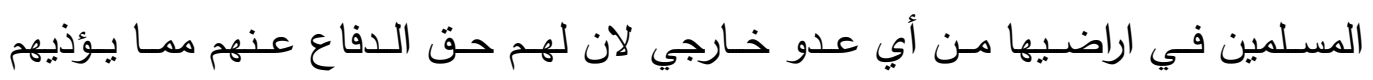

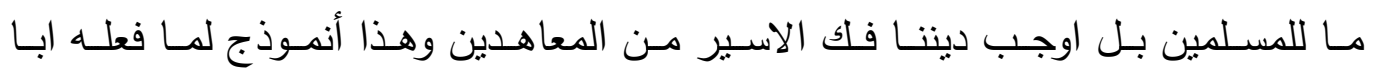

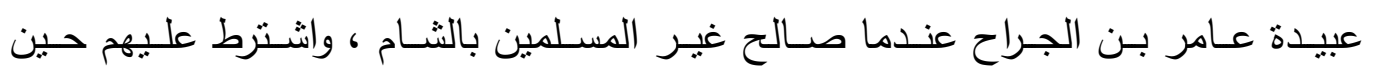

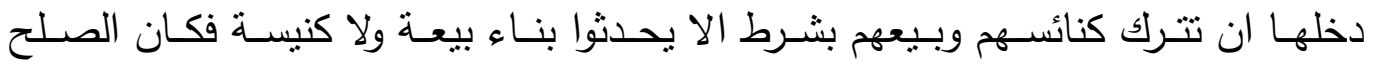

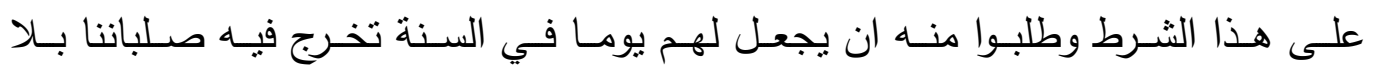

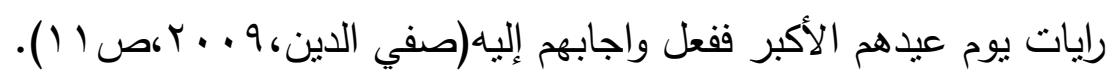

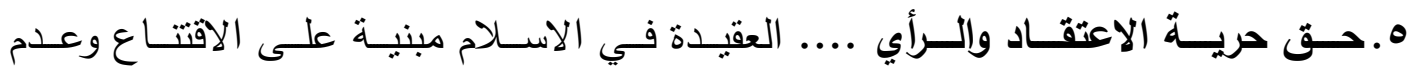

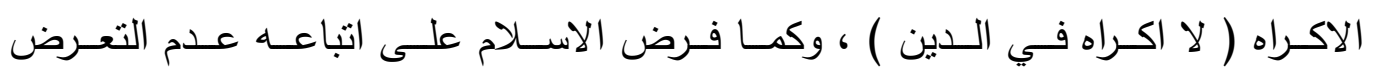

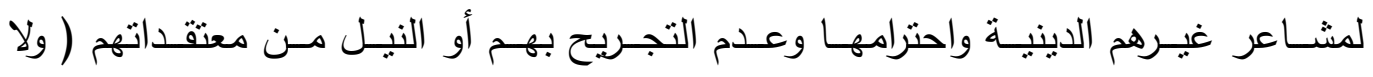

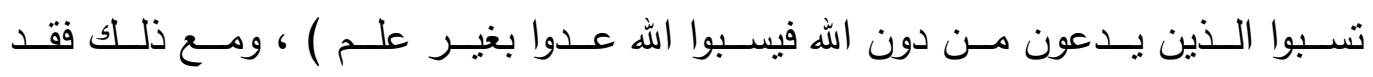

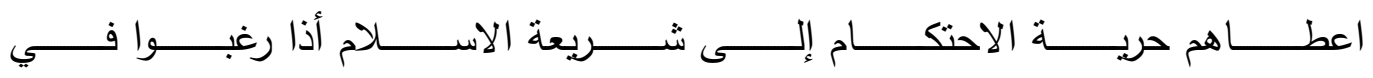

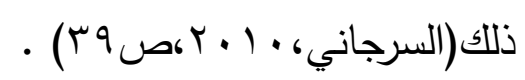

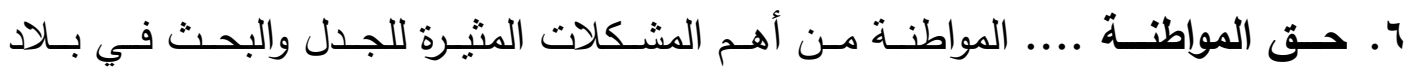

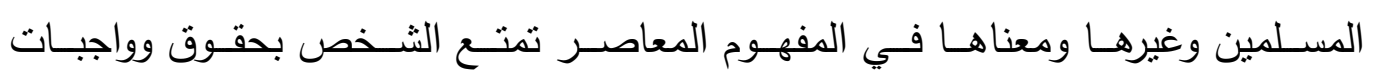

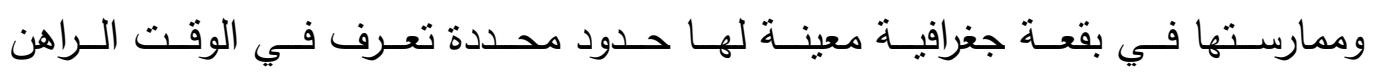

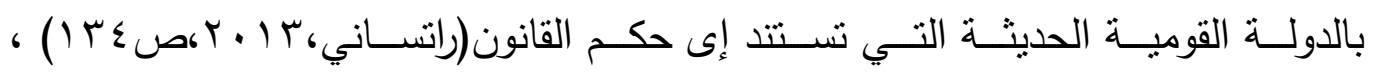




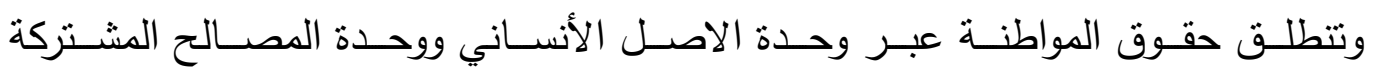
والآمال والآلآم.

ثانياً : الحقوق الاقتصادية ومنها لـالام.

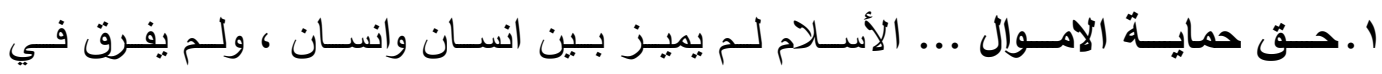

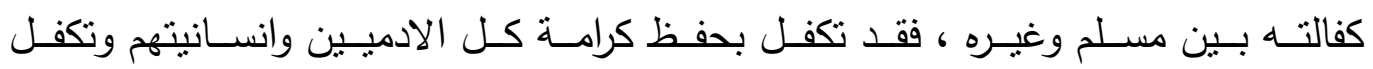

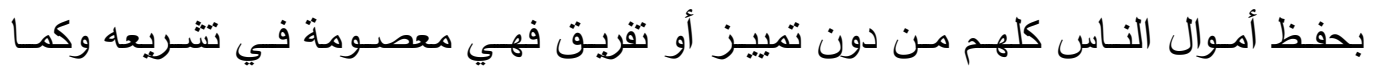

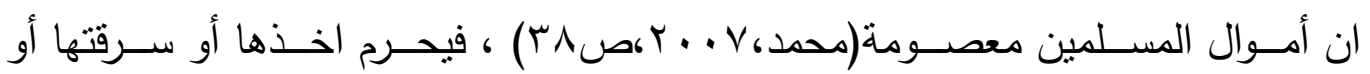

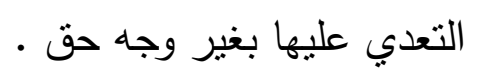

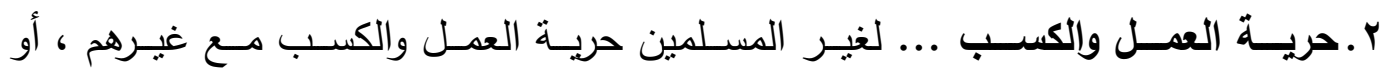

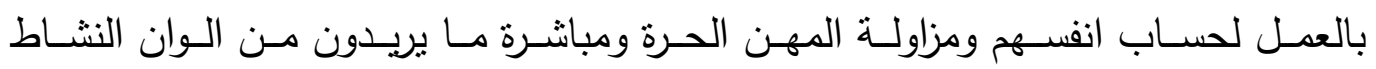

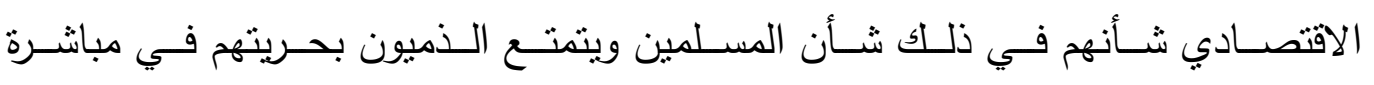

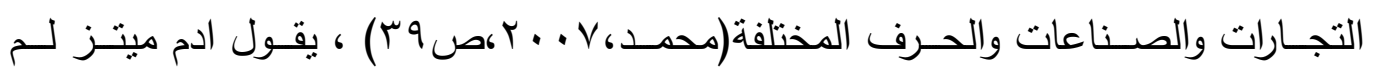

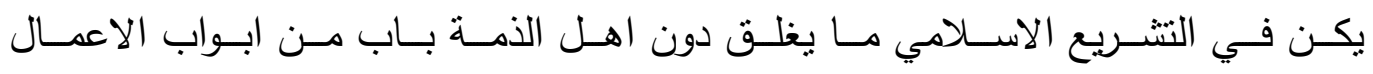

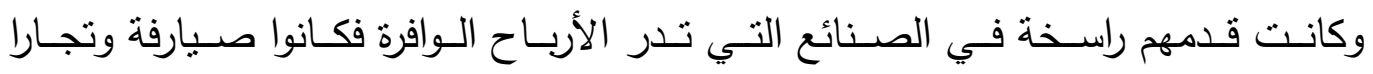

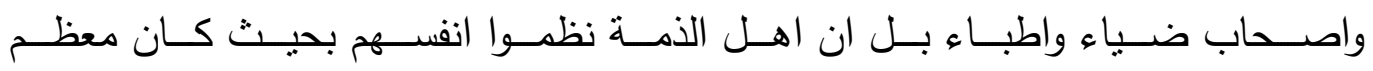

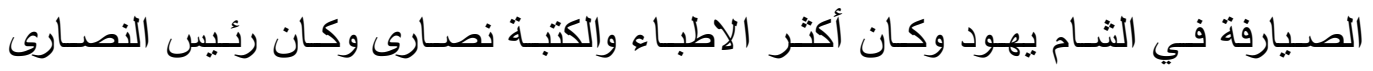

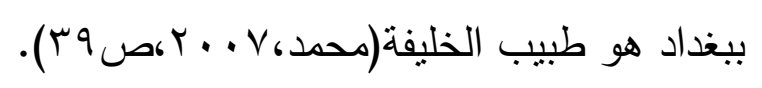

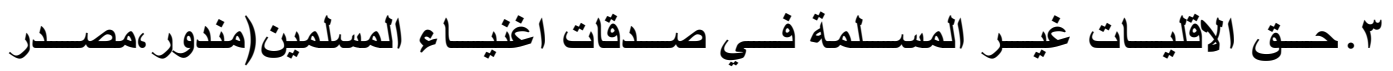

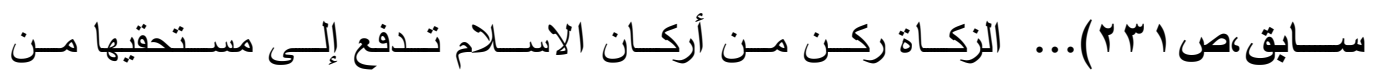

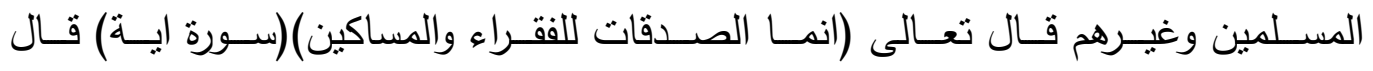

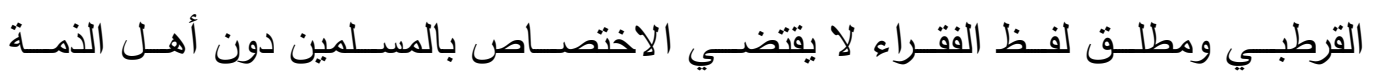

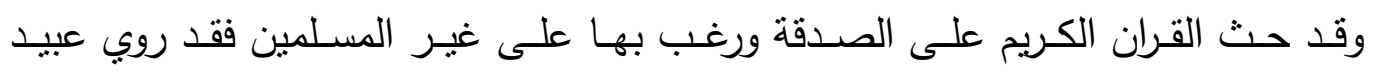

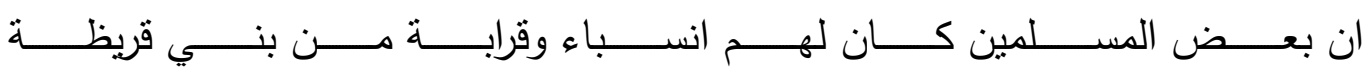

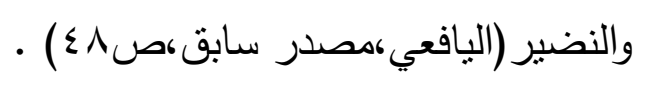

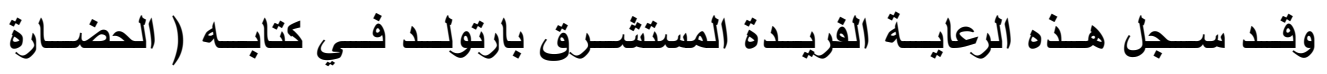

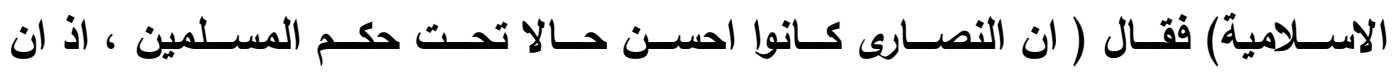

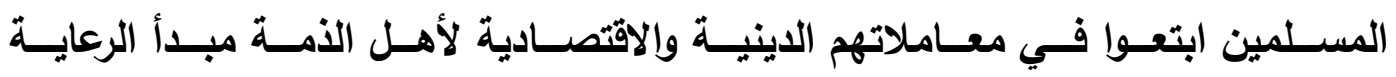

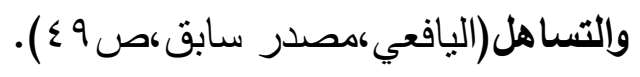


ثالثاً : الحقوق الاجتماعية ....وتتضمن :

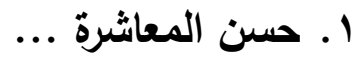

الفكر الاسـلامي يحـث على الاحســان إلـى أهـل الكتـاب واخـذهم بحسـن المعانــرة

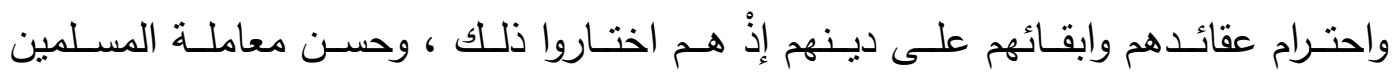
لأهـل الكتاب جعلتهم يجدون منهم المطلـوب في كنف المسلمين ويحسـون بالطمأنينـة

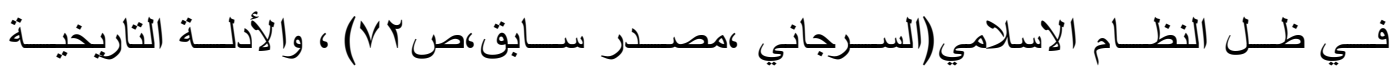

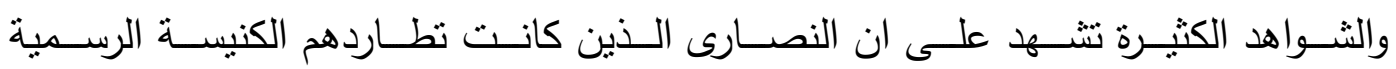

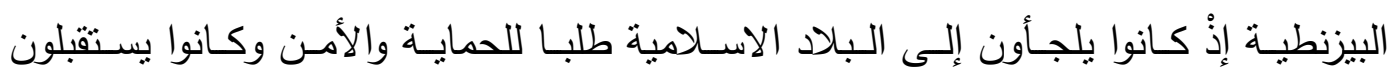

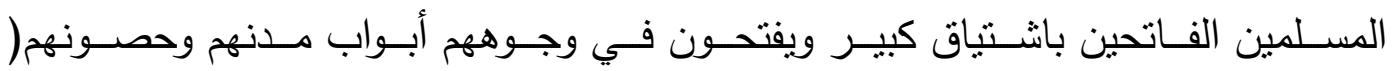

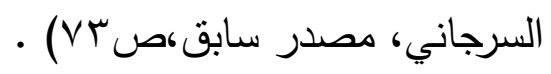

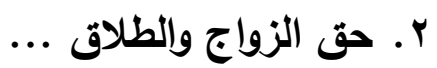

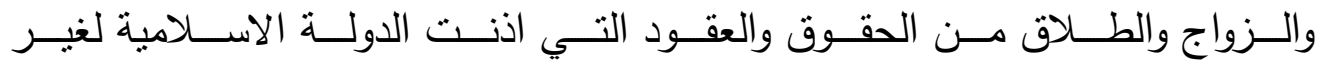

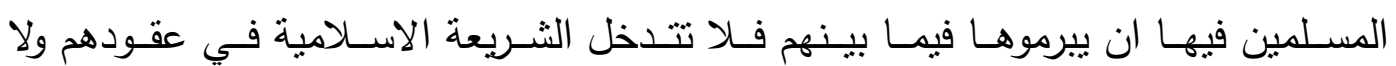

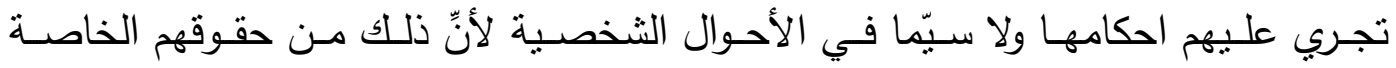

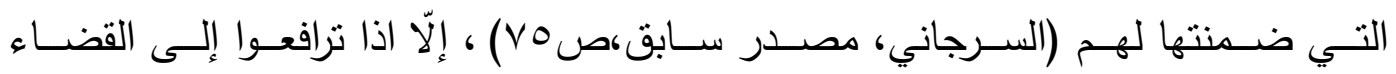

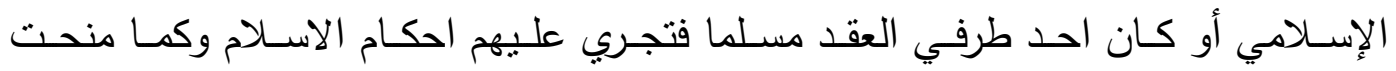

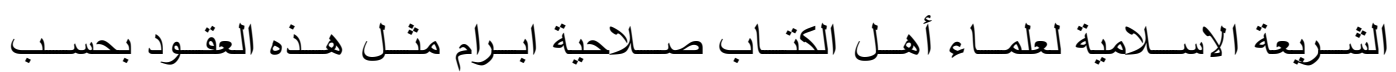

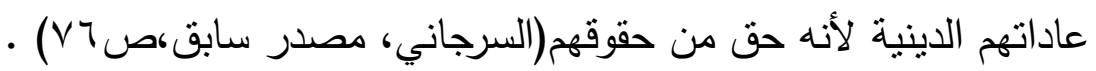

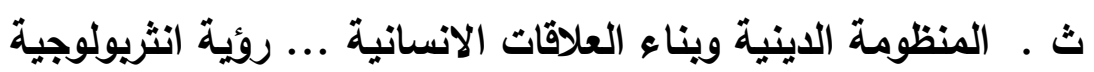

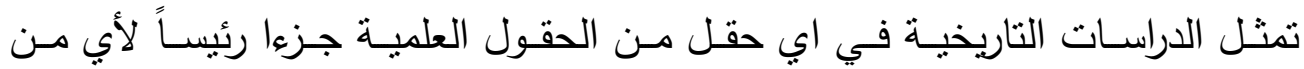

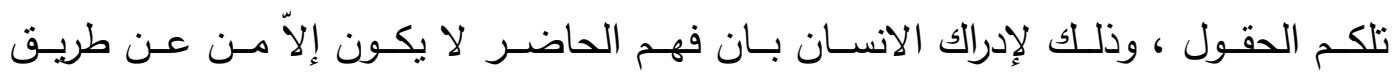

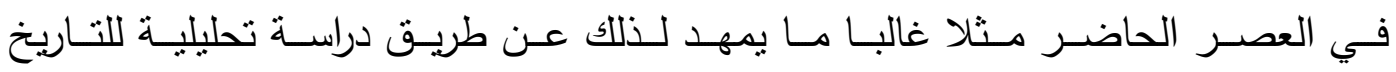

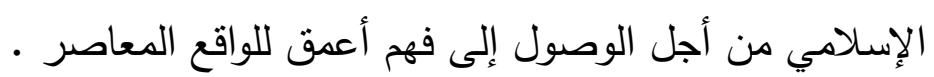

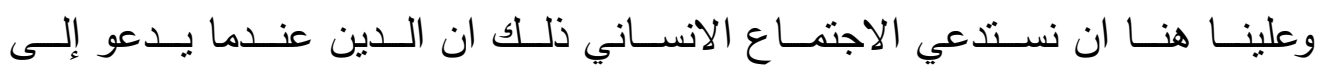

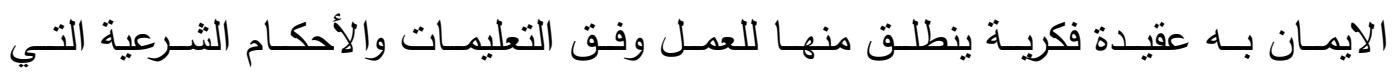

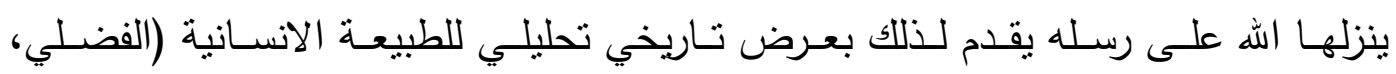

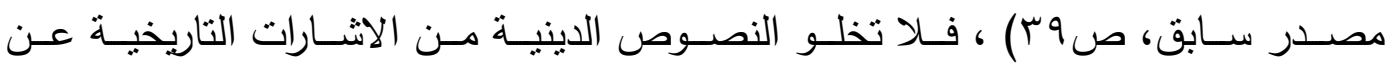

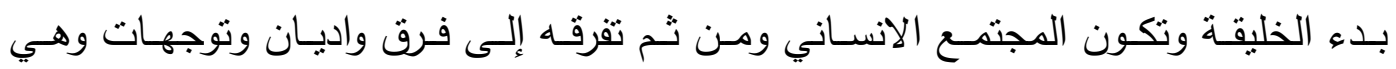

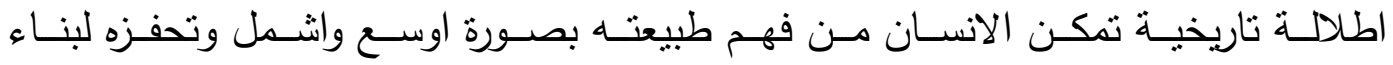

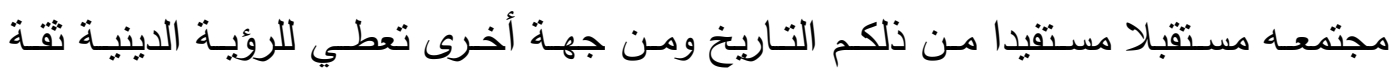


اكبر ، وهنـا تـأتي المنظومـة الدينيـة التي ترتكـز في جـزء منهـا على النظـام الاجتمـاعي مـن اعـراف وتقاليــــــنظم علاقـات الافـراد فـي المجتمـع فالنـاس اولا يتعـاملون مــع الأخـرين بفطـرتهم ومـن ثم تـأتي المنظومــة الدينيـة تحـرك وتوجـهـ هـذا العلاقـات ضــن سـياقات تاريخيـة واجتماعيـة وفكريـة وكـل الاثــارات التاريخيـة للفكـر الاســلامي تثــير إلى دور الانسـان ووعيـه لماضـيه وينطلـق منهـا إلى حاضـره ليثـكل نمـط العلاقـات مـع الأخرين ايا كان مذهبهم أو دينهم أو عرقهم •

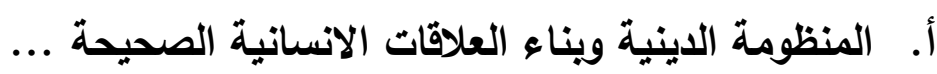

حينمــا يصــف الله تعـالى العلاقـة الانســانية فـي المجتمـع المسـلم يصـفها بإنّهـا علاقـة أخويـة قائمــة على مبـدأ الايمـان بـاله وهـو مـا يعنـي ان اسـاس العلاقـة الانسـانية

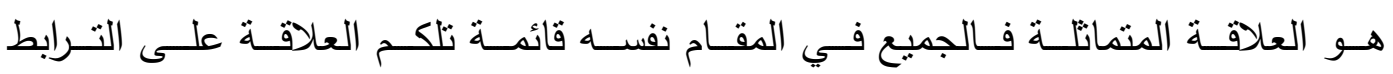
الاخوي والتراحم والتواصل (الفضلي، مصدر سابق، صولم). وقـد حصـلت انعطافـه في حيـاة النـاس عـن المبـادئ والقيم سـببها الانانيـة وحـب

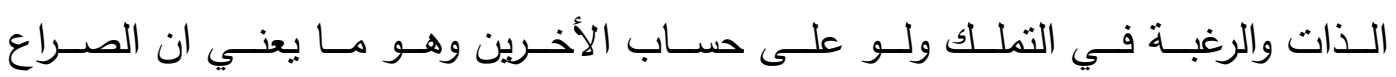
البشـري يرجـع في اساسـه إلـى عوامـل داخليـة في الـذات الانسـانية فصـراعات الحاضـر والماضي انما هي نابعة من الانسان ذاته وليس من عوامل خارجية دائما .

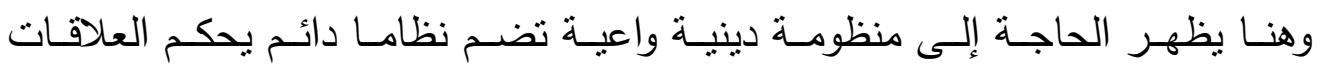
الانسـانية بمـا يخفـف مـن وطـأة هـذه الـروح ، وان التـزام الفـرد بهـذه المنظومــة يقي المجتمـع مـن مضــار الصــراعات التـي تـؤدي إلـى معانـاة المجتمـع وتوجـب علـى الفـرد

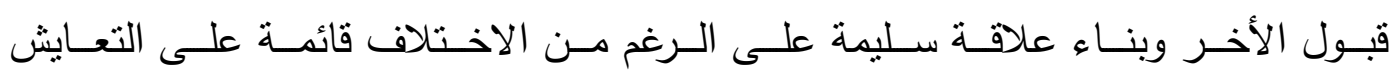
والتسامح والتثاقف .

\section{ب. التعدد والتنوع ... سمة وضارية}

التعـدديات الانسـانية ظـاهرة اجتماعيـة طبيعيـة ، وتمثـل لونــا مـن ألــوان الأبـداع الالهـي فـي خلـق الانسـان ، ومـا ينزلـه الله مسن رسـالات لا تهـدف إلـى تـذويب هـذه

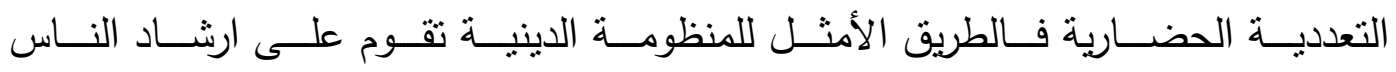
للتعـايش بـين الفـرد والمجمـوع ومـع المحـيط بصـورة سـليمة حفاظـا علـى النـوع الانسـاني وحفاظـا على مـا حولـه مـن مقدرات الطبيعـة التي سـخرها الله لجميـع عبـاده على الـرغم من اختلافهم ليتشاركوا فيها وينعموا بخيراتها (الفضلي، مصدر سابق، ص • ع) .

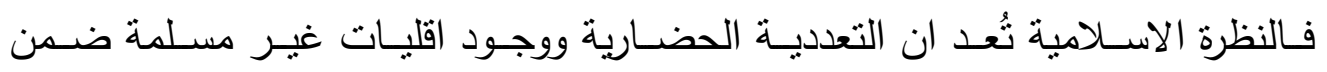
بنائهـا الاجتمـاعي حقيقـة واقعيـة وتمتثل مظهـرا مـن مظـاهر الأبـداع الالهـي للإنســان 


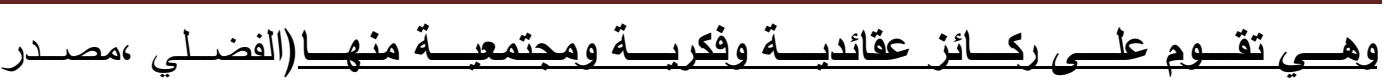

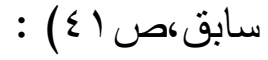

ا. الدعوة إلى الايمـان بالرسـالة الالهية ، والعيش ضمن وحدة اجتماعية تقوم على التكافل

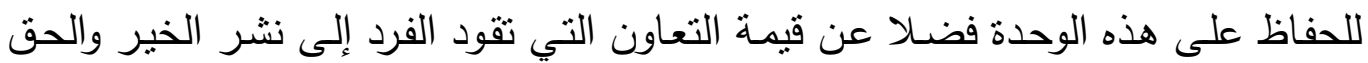

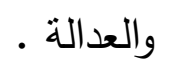

r. حددت الكتب والصحائف السماوية وصولاً إلى القران الكريم الذي نسخها كلها إلى البحث

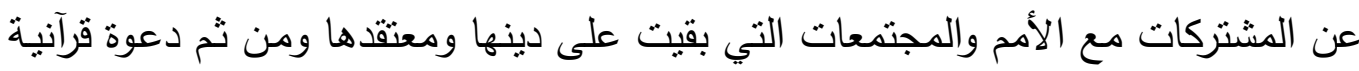
إلى تقديم لغة الحوار والتعاون وتقبل الأخر . r. الحوار في الفكر القرآني قائم على ان الحوار يقوم بوجود هويات متمايزة (الاقليات غير

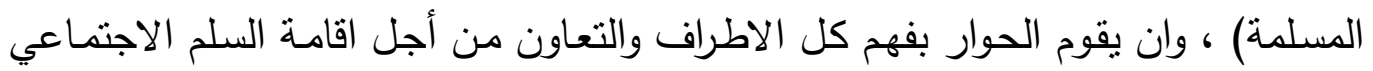

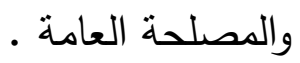
المحور الثالث

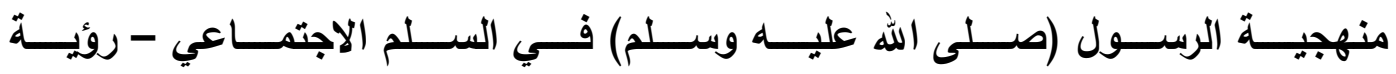
انثريولوجية تحليلية

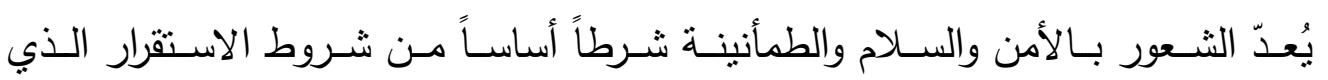

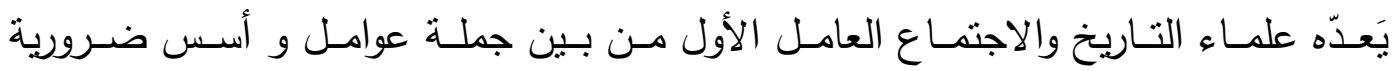

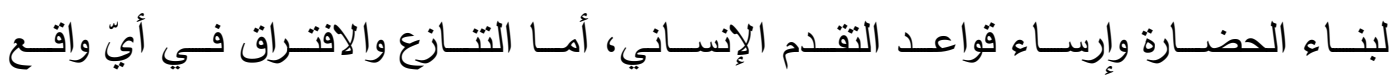

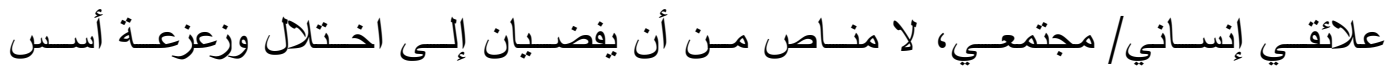

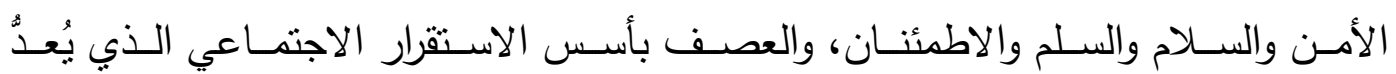

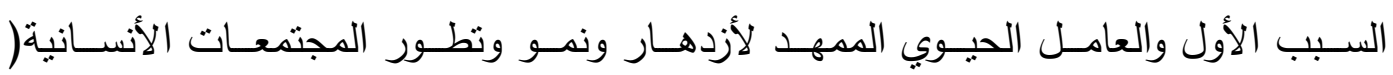

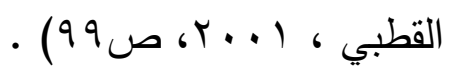

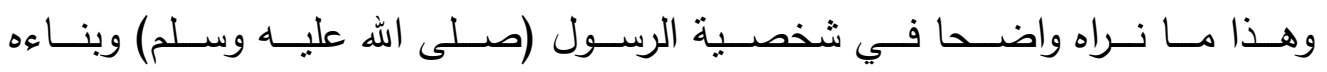

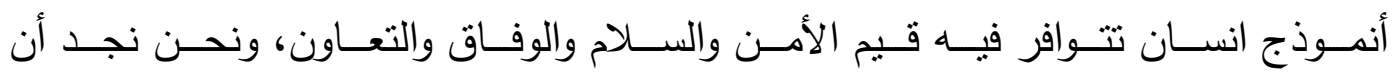

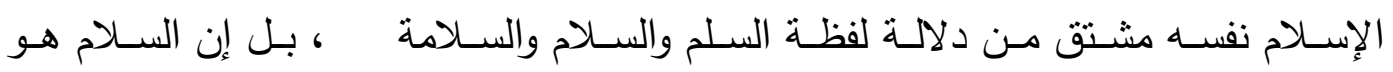

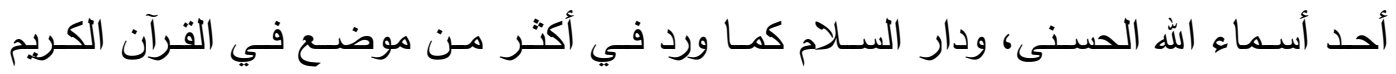

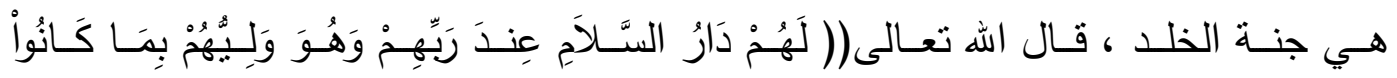

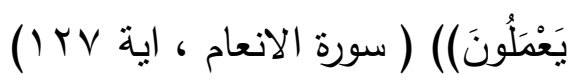

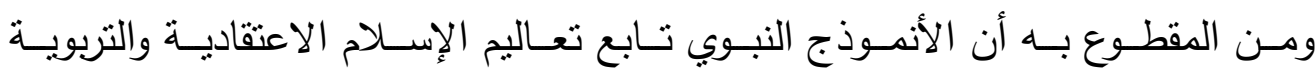

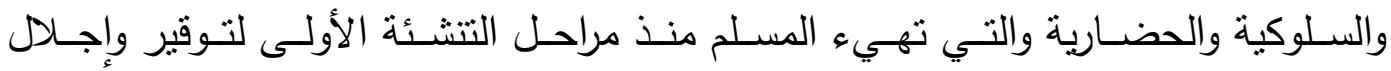

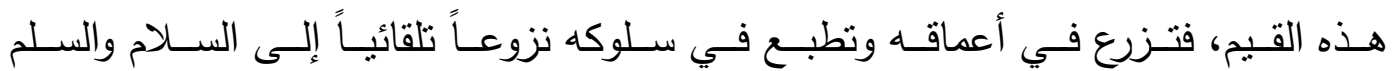


والمســالمة والمعايثـة ، حتـى أن كلمـة السـلام ومشـتقاتها ذكرت في القـرآن الكريم أكثر

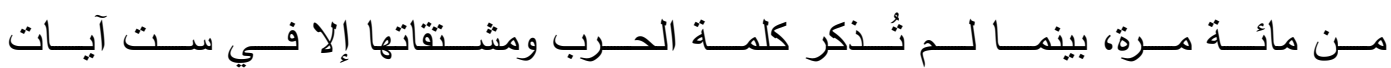
فحسب(اليافعي ،مصدر سابق،صنم0). وبنـاءً على ذلك فـإنَّ المسـلك الأرشـــ والأقـرب إلـى الحكمـة والصـواب، اتكـاءً على هـذه المعادلـة، فضـلا عـن أرضـية الوحدة التي هيأهـا الأنمـوذج النبـوي السـلوكي في في

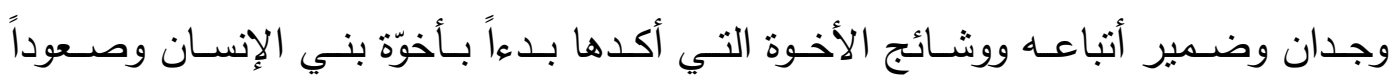

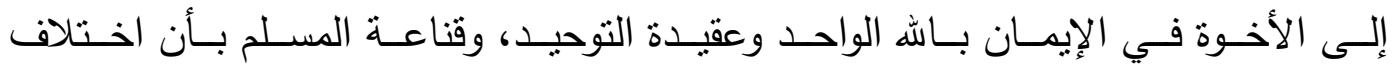
الأجنـاس والمعتقـدات والقناعـات والـرؤى إنمـا هـو ســنة مـن سـنـن الله تعـالى فـي خلقـهـ وفـي حقيقـة الاجتمــاع الإنســاني، أن ينـأى المسـلم عـن الغلــو والتطـرف فـي الآراء

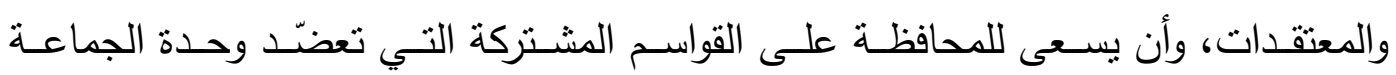
والمجتمـع الـذي ينتمـي إليـه، فـلا يكـون أبـداً معـول هـدم يسـعى في تـدميره أو تخربيـه

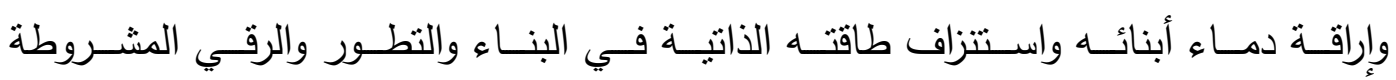
أصلاً بتحقّق عامل الأمن والاستقرار والسلام. واءله

لقـد كـرس رسـول الله (صـلى الله عليـهـ وسـلم) أنموذجـه في بنـاء شخصـية الانسـان

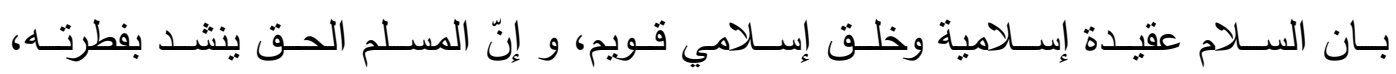

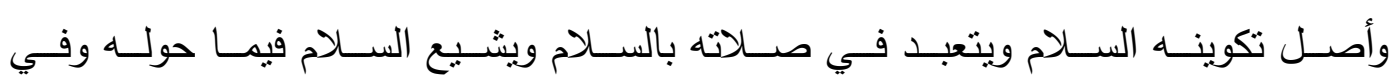

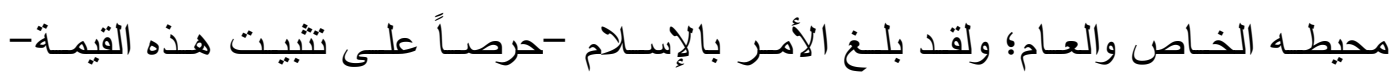
أن دعـا أتباعـه وأرشـدهم إلىى عدم تمنـي لقـاء العـدو، لكن مـع ضـرورة التشـبث بالصـبر وبـذل الوسـع فـي المغالبــة، والإصــرار عـى النصــر فـي حـال اللقـاء( صـفي الـدين (مصدر سابق،صع ع ( ).

وذلكلك مـن بـاب التشـديد والرغبـة في إرسـاء دعـائم السـلم والسـلام، كمـا أن الإســلام

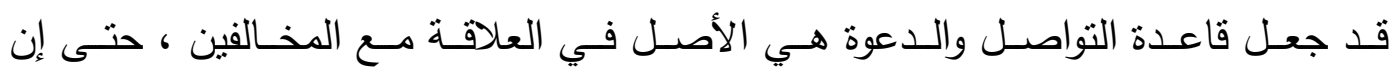

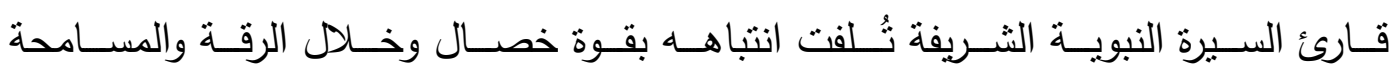
والحـرص على توطيـد روح السـلم والمؤاخـاة والنـأي حتـى عـن الألفـاظ والأسـماء التـي توحي بنقيض تلك الخلا الإنسانية النبيلة الرقيقة. ومـن ذلـك -علـى سـبيل المثـال ولـيس الحصـر - أن النبـي صـلـى الله عليـهـ وسـلم كـان يكـره مجـرد كلمـة “حـرب" ولا يحــب سـماعها، و لقـد علّم أصــحابه قـائلا: أحَبِّ الأســماء إلـى الله : عبــدالله وعبــدالرحمن، وأصــدق الأســماء: حـارث وهمــام، وأقَّبح

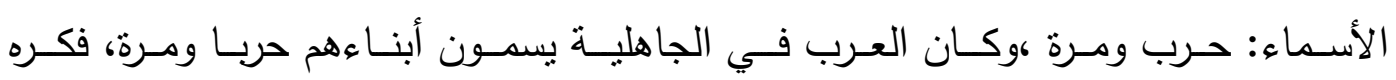

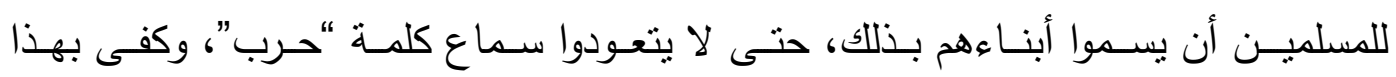


حرصـاً مـن رسـول الله ومنهجيـة الإسـلام على الســام والأمـن والطمأنينـة (صـفي الـدين

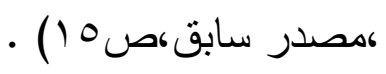

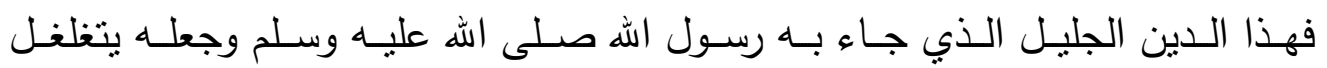

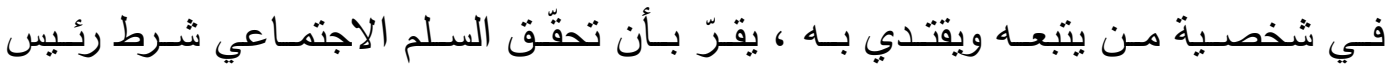

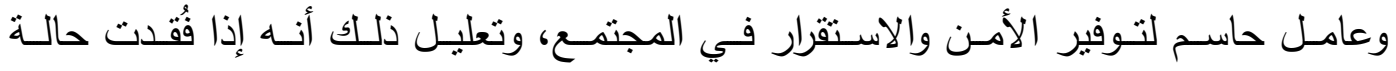

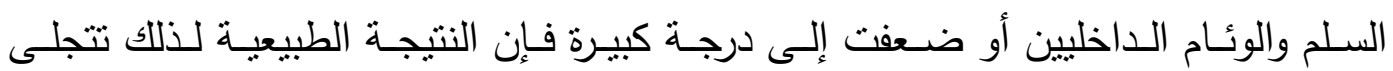

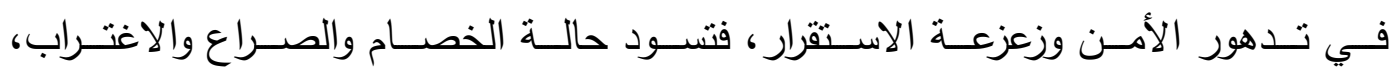

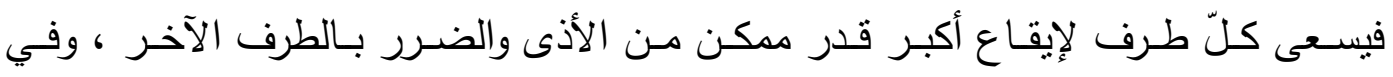

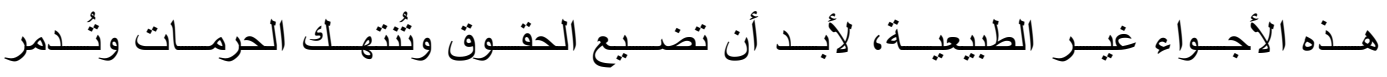

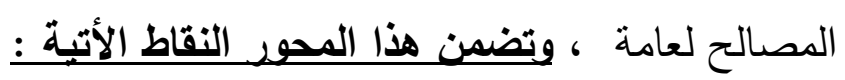
أولاً : المرتكزات السلوكية النبوية للسلم الاجتماعي مع الاقليات غير المسلمة . .

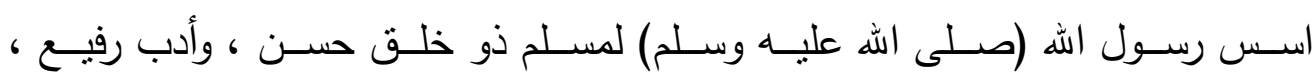

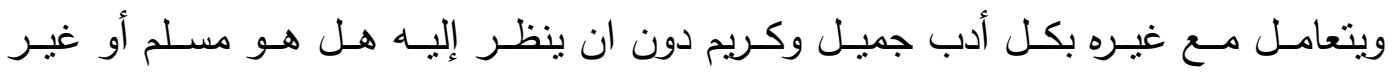

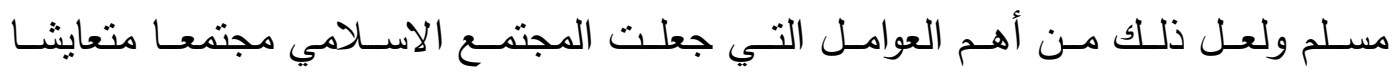

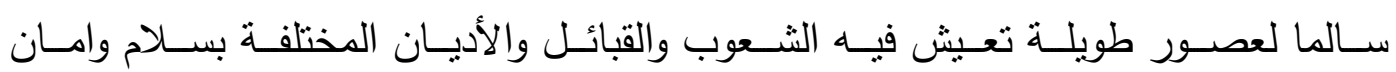

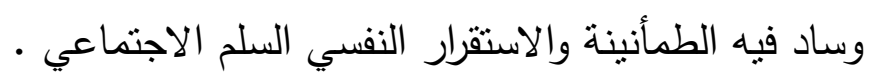

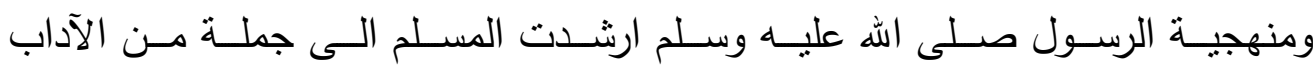

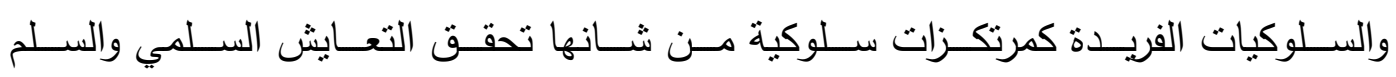

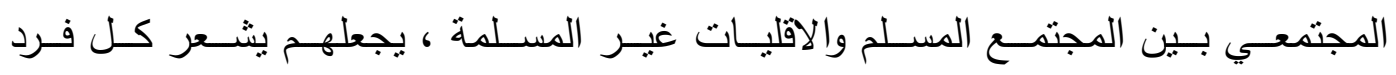

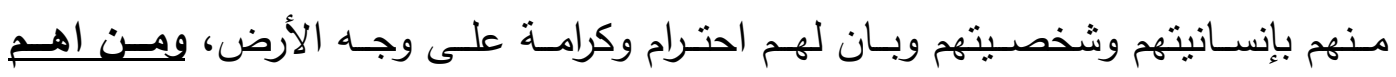

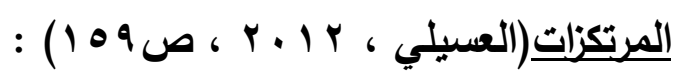

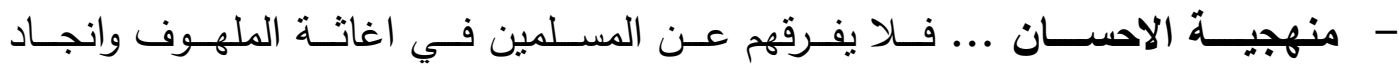

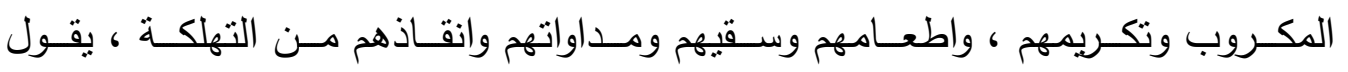

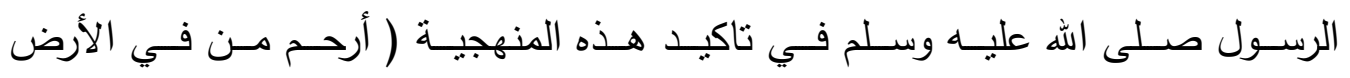

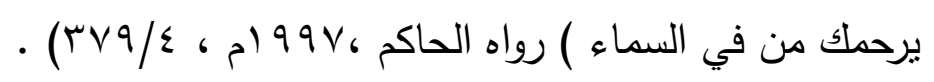

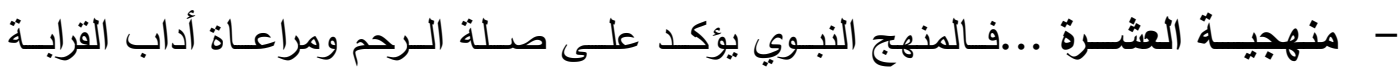
بغض النظر عن الدين أو المـذهب العقائدي وربمـا تصـل هـذه الآداب حتى خـارج بلاد المسلمين - منهجيـة العـل وكـف الظلـم والتعدي ...وتتطبق هذه القاعدة السـلوكية على امسوال

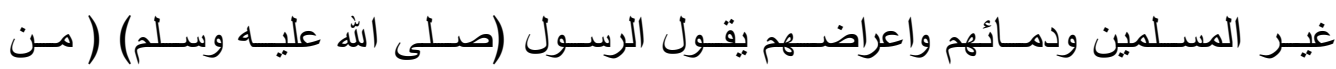




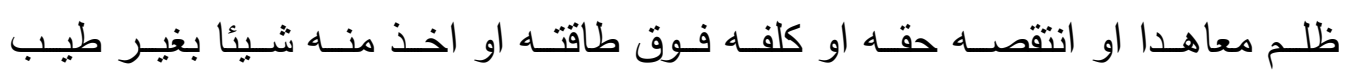

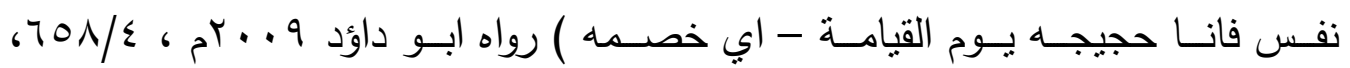
ويؤكد المـنهج النبـوي على موضـوع التحـير الثـديد والكبيـر اذا بلــن الظلـم والتعـدي

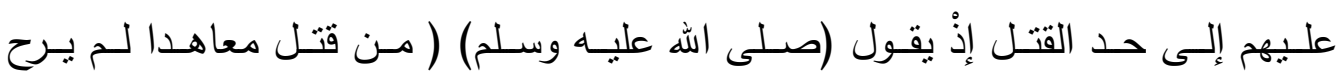

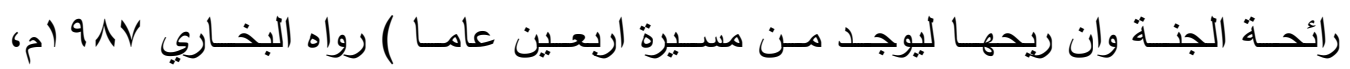
$.1100 / r$

ولا يخفـى مـا لهـذا الاســاس المتـين والتوجيـهـ الرشـيد مـن منهجيـة واضـحة فـي الســلم الاجتمــاعي والتعامــل مـع غيـر المسـلمين الـذين يعايثــون المســـين فـي دولـة واحدة ومجتمـع واحـد كي يبتعـد المجتمـع المسـلم عـن كـل مـا يبــث الكراهيـة والثـحناء وبعيث الفساد ولكي يكون هناك عيش بسلام وأمان وسلم اجتماعي • - منهجيـة العلاقـات الاجتماعيـة ... وقد أسس لها رسـول الله (صـلى الله عليـه وسـم) بمقومـات العلاقـات الاجتماعيـة الفاعلـة فيزور مريضـهم ويعايشـهم في السـراء والضــراء

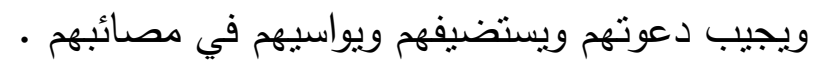
- منهجية الالتزام بالسـلوكيات الصحيحة ..كالصدق والأمانة والعدل والانصاف والرحمة وقد كان رسـول الله (صلى الله عليه وسـلم) يحترمهم ويقدرهم في حال حياتهم ومـوتهم ويعاملهم كانسان مكرم مربيا اصحابه على هذه السلوكيات .

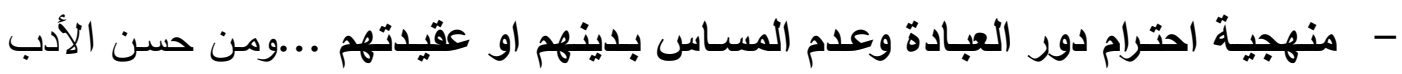
ومنهجيـة الرسـول في التعامـل مـع الاقليـات غير المسلمة في المجتمـع الاسـلامي عدم التعرض لعقيدتهم وشعائر دينهم بسوء أو سخرية مع الحفاظ على دور عبادتهم وسـامتها وهذا من مقتضيات الحربة الدينية التي ضمنها لهم المنهج النبوي ، وحتى أوقات الحروب والأزمـات فيجـب تـركهم يمارسـون شـعائرهم الدينيـة بكل حريـة ويضــنـون لهم الأمـان والسلامة .

ثانيـاً : نمــاذج سوسـيوانثربولوجية للمرتكـزات السـلوكية النبويــة للســلم الاجتمــاعي مع الاقليات غير المسلمة لأبــــ القـول ان منهجيـة الرسـول الاعظم تجمـع بـين التعليم والتطبيـق مسـتمدا هـــه

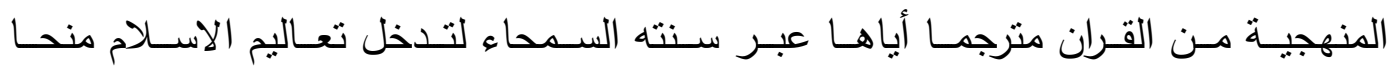

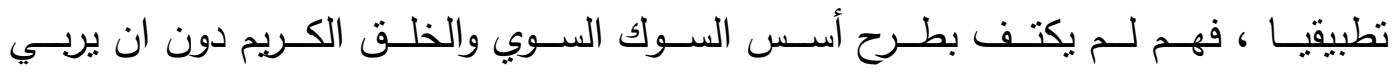
المسـلم واقعيـا على الالتزام بهـا لـذلك نـرى ان تـاربخ المـنهج النبـوي وسـيرته العطـرة قـد حفلــت بنمـاذج سوســيوانثربولوجية و واقعيــة ومجتمعيــة شــعرت بهــا الاقليـات غيــر 


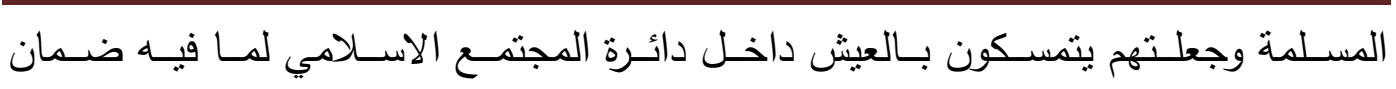

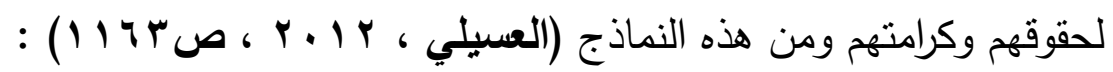

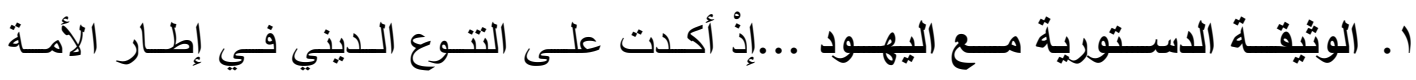

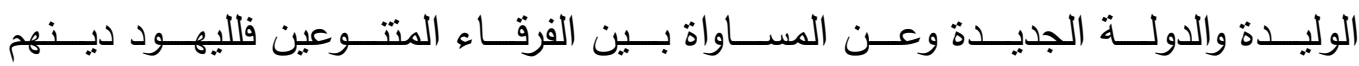

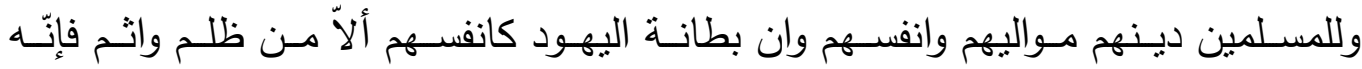

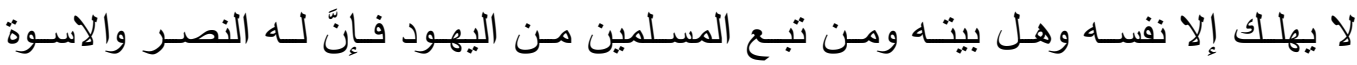

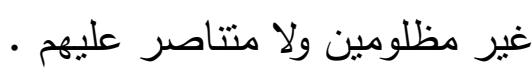

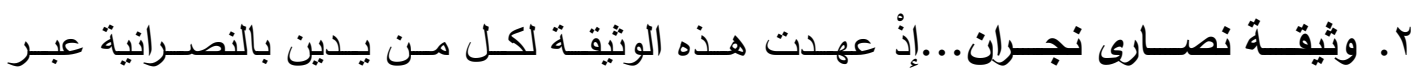

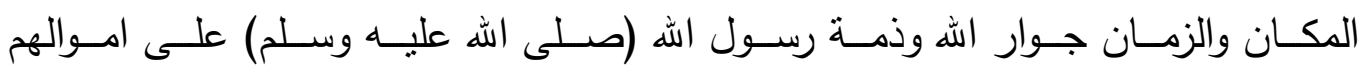
وانفسـهم وملتهم وغـائهرم وشـاهدهم وعشـيرتهم وبيعهم وكل مـا تحت أيديهم مـن قليل

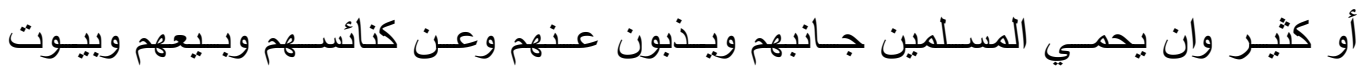
صـلواتهم ومواضـع الرهبـان ومهواطن السياح وان يحرسـون دينهم وملتهم ايـن مـا كـانوا

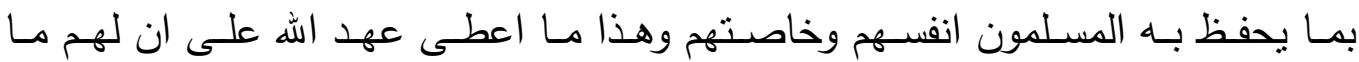
للمسـلمين وعليهم مـا على المسـلمين وعلى المسـلمين مـا عليهم حتى يكونـوا شـركاء

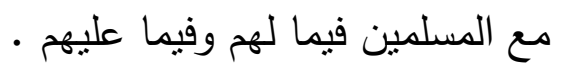

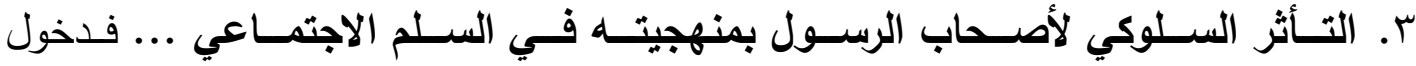

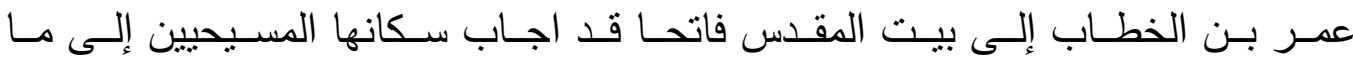
اشـترطوه مـن ان لا يسـاكنهم فيهـا يهـودي وتحـين صــلاة العصـر وهـو فـي داخـل

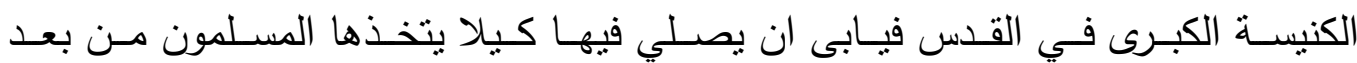

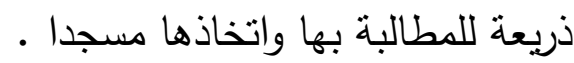

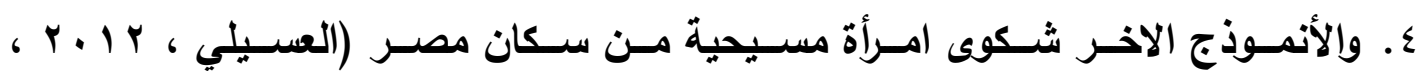

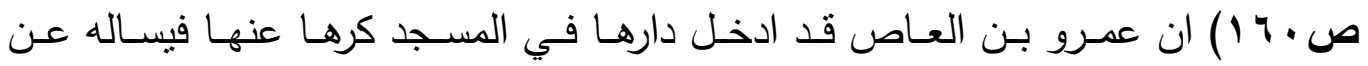

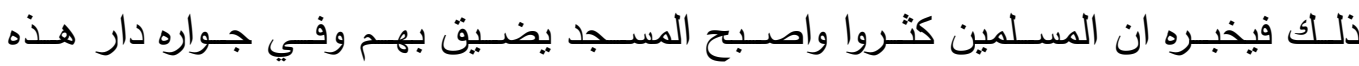

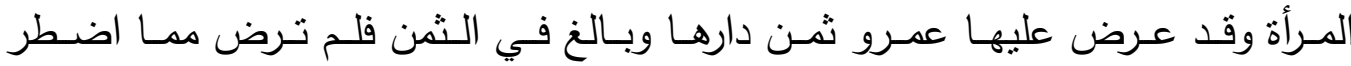

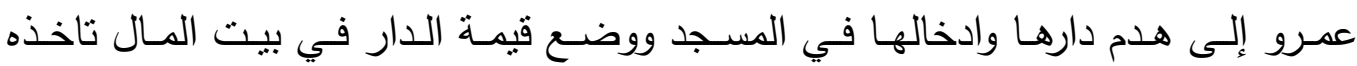

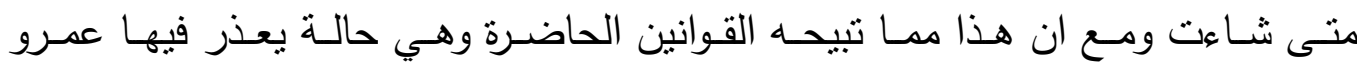

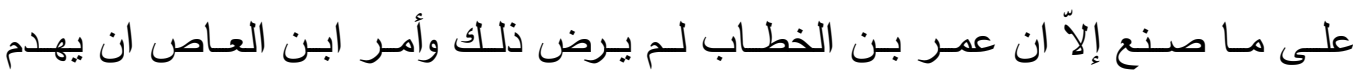
البناء الجديد من المسجد ويعيد إلى المرأة المسيحية دارها وكما كانت. 
ونـرى فـي ضـوء هـــه النمـاذج السـلوكية حقيقـة السـلم المجتمعـي الـذي أسـس لـه

رسـول الله ( صـلى الله عليـه وسـلم ) بمنهجيـة حياديـة متينــة قائمسـة على ركـائز قرانيـة ونبويـة تحـاكي الواقـع الاجتمـاعي وجعـل منهـا مبـدأ اصـيلا يـدل على تسـامح الاســلام

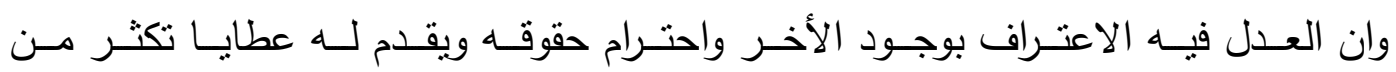
حقوقـه وهـذه هـي حقيقة السـلم المجتمعي ومـن جهـة أخـرى فـان السـلم الاجتمــاعي في الاســلام والتشـامح هــا ثمرتـا تصــور المسـلم للكـون والحيـاة والانسـان وانعكـاس لالتـزام المسـلم بدينـه وسـعيه لتطبيـق احكامسه ويصـبـح فيمـا بعـد عقبـدة ومـنج وسـلوك ونظربـة وتطبيـق عنـدما يـرى افـراد المجتمـع المسـلم ان هنـاك منهجيـة للكارزمـا النبويـة في قيـادة هـذا الملـف مـن حيـاتهم والتعامـل معـه بجديـة ورصـانة اجتماعيـة محافظـا على الهويـة

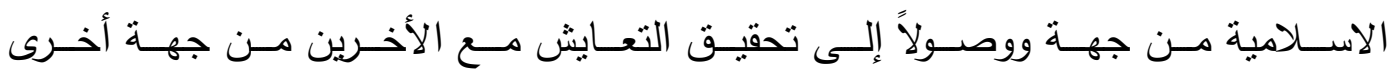
مطبقين قوله تعالى (( ياايها الناس انا خلقناكم ....)) • المحور الرابع : استتتاجات سوسيولوجية للبحث ومقترحات اولاً : الاستتناجات

ا ـ خصوصية المجتمع الاسلامي واتصافه بسمات عقائدية وفكرية وسلوكية .

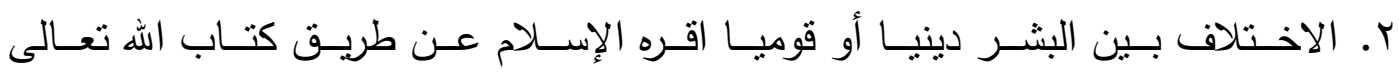

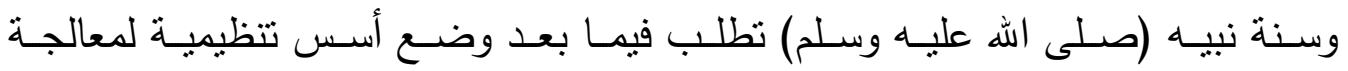

$$
\text { هذا التتوع والاختلاف في التاريخ الاسلامي • }
$$

r. تضــن المـنهج الاســلامي حقوقـا فريـدة عاشـتها الاقليـات غيـر المسـلمة في المجتمـع الاسـامي مستتدة على فلسفة التشريع الاسلامي وضامنة لها .

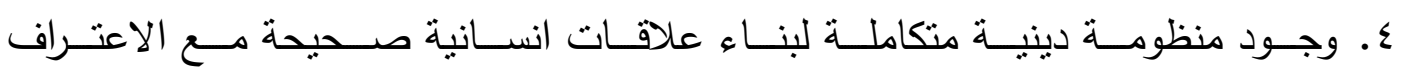
بالتعدد والتتوع كسمة حضارية وظاهرة اجتماعية طبيعية . هـ منهجيــة نبويــة راقيــة لبنـاء انســان تتـوفر فيـهـ معـاني الســلام والأمـنـ والتعــاون والتعـايش مــع الأخـر أيـا كـان ، وبنـاء مرتكـزات السـلم الاجتمــــي بثـكل منهجـي - ومنظم

7. قـراءة للنمـاذج النبويـة في السـلم الاجتمـاعي نلاحـظ انهـا انطـوت واسســ لعلاقـة

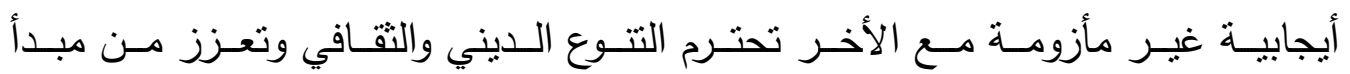
التعايش السلمي. ثانياً : المقترحات - قراءة موضـوعية جديدة لكثير من النصـوص الاسـلامية التي تبنـي علاقة أيجابيـة مـع

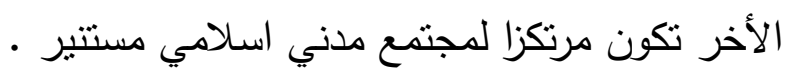


- أعادة النظر في كثير من الاجتهادات والفتاوى القديمة والمعاصرة والتي ربما كانت سببا

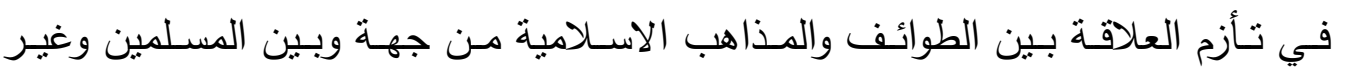

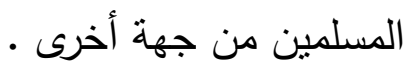

- أعادة انتاج منصة فكرية تضم المفكرين والفقهاء وصناع القرار والناشطين في مؤسسات

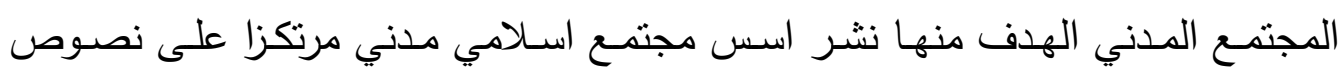

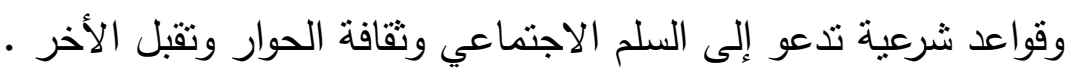

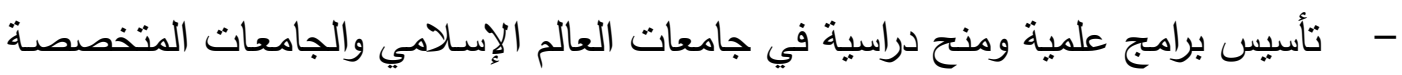

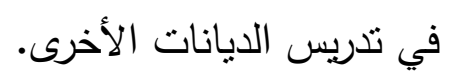

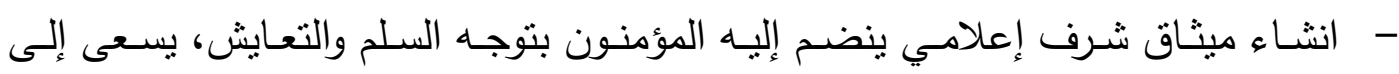

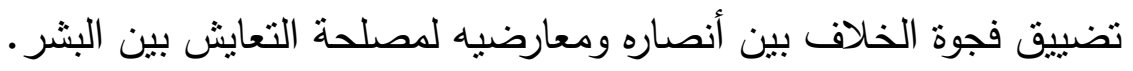

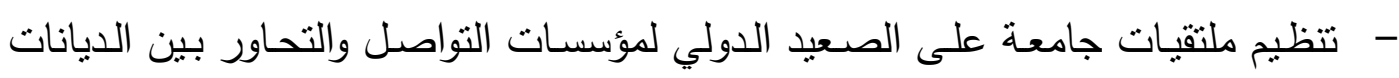

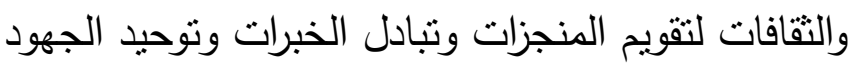

المصادر - القران الكريم - (المبان

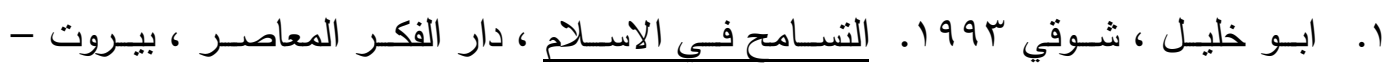
• لبنان

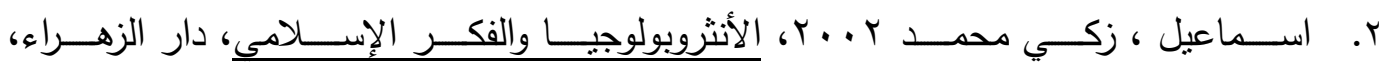

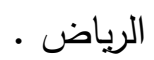

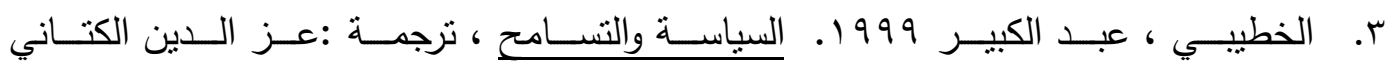
الادريسي ، المجلس الاعلى للثقافة ، المشروع القومي للترجمة ، القاهرة .

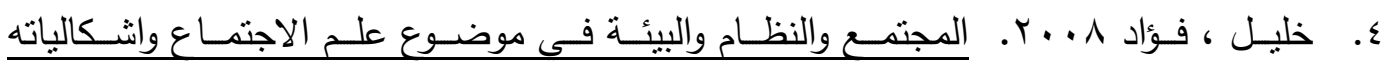

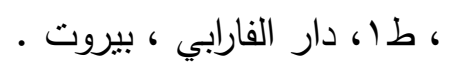
0. الخولي ، سناء .191. . مبادئ علم الاجتماع، دار الكتب الجامعية، الإنكندرية.

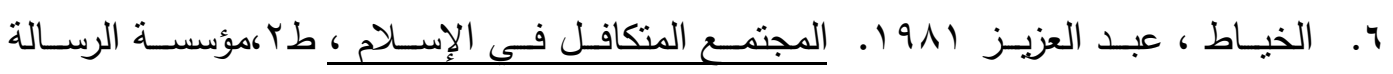

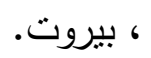

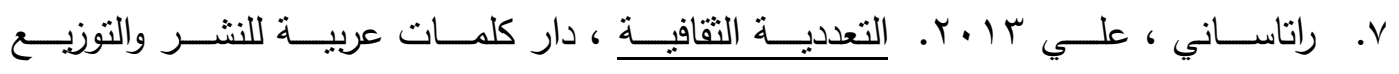
- مصن

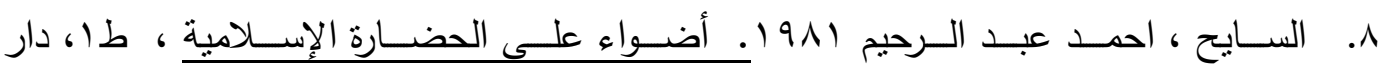
اللواء

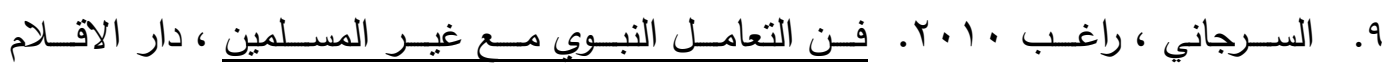
للنشر والنوزيع والتزجمة ، القاهرة . 


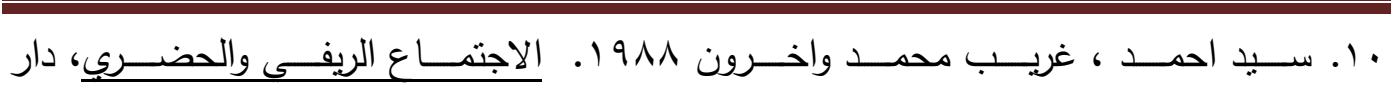

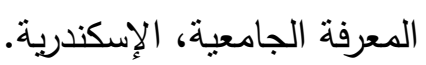

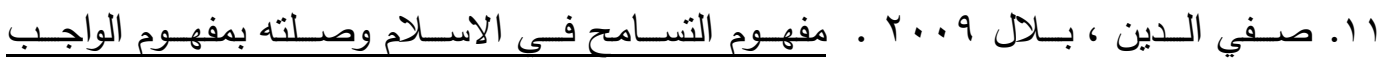

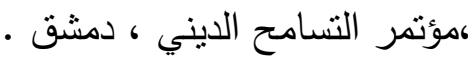

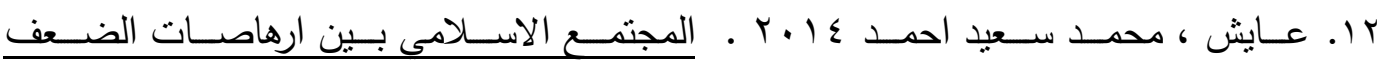

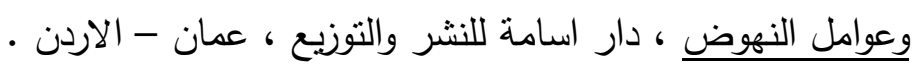

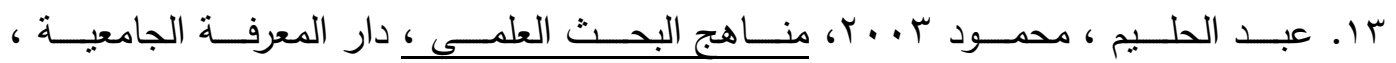

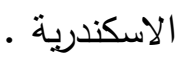

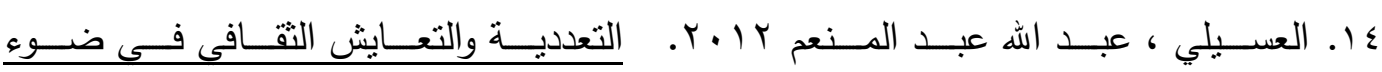

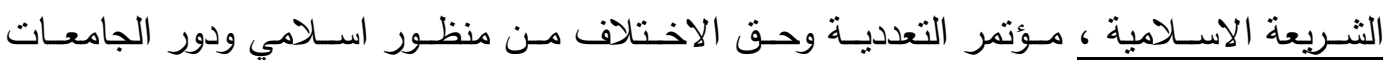

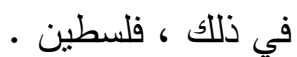

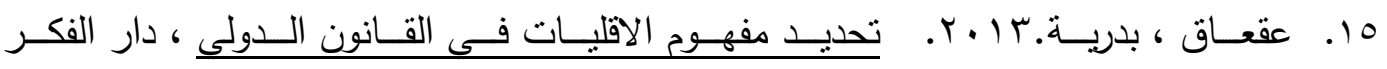
والقانون ، المنصورة ، مصر . بات.

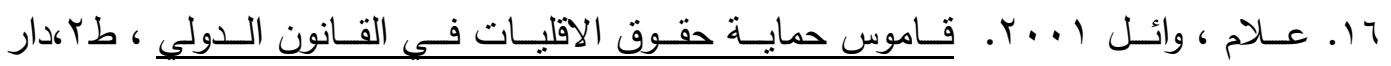

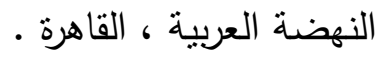

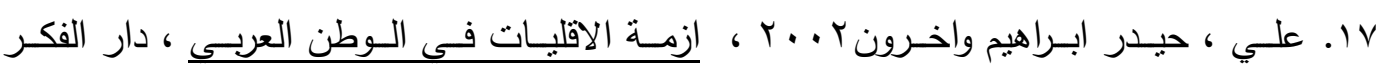

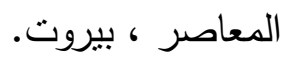

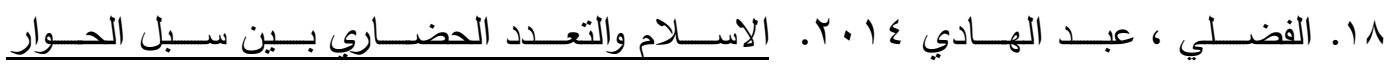

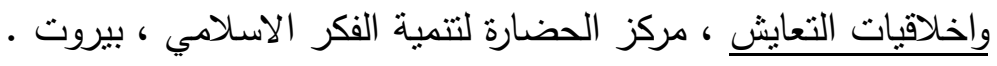

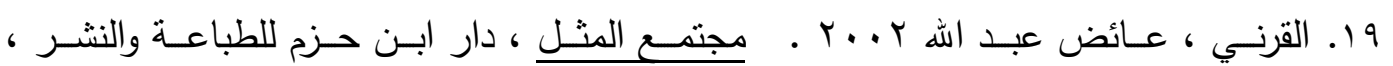

$$
\text { بيروت }
$$

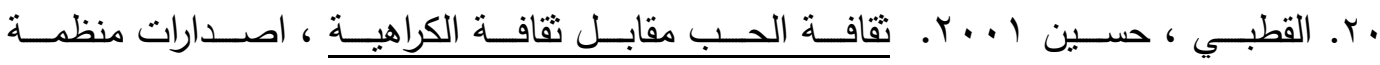
التنمية والتعايش السلمي العراقية .

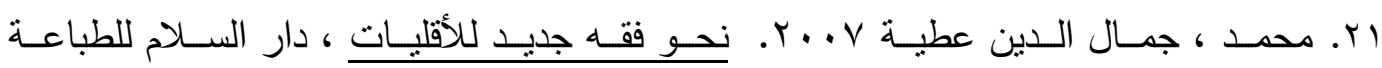
والنشر والتوزيع ، القاهرة .

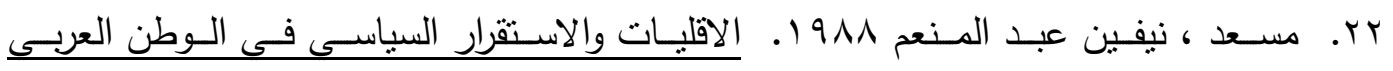

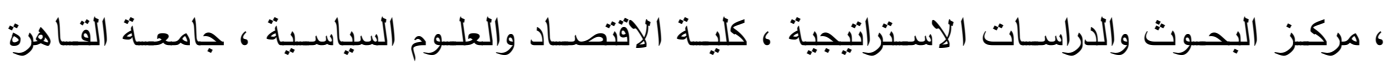
، مكتبة النهضة المصرية ، القاهرة .

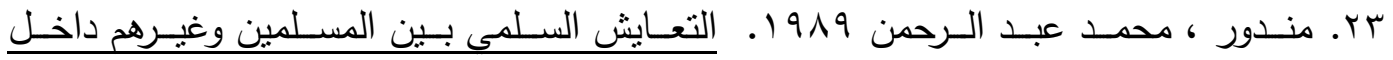
دولة واحدة ، دار السلام للطباعة والنشر ، القاهرة .

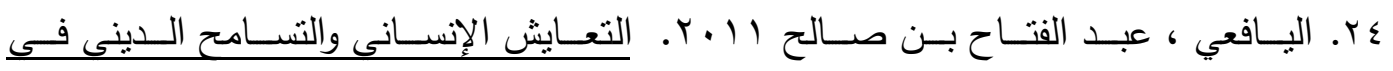

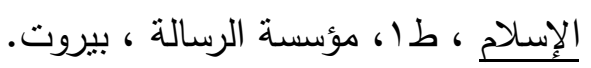


المسـلمون بـين المواطنـة الدينـــة والمواطنـة السياسـية ، دار المعـارف

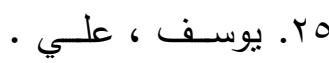

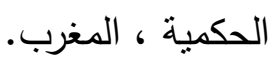

References:

Abdel Halim, Mahmoud 2003, Curricula for Scientific Research, University Knowledge House, Alexandria.

Abu Khalil, Shawky, 1993. Tolerance in Islam, House of Contemporary Thought, Beirut-Lebanon.

Al-Fadhli, Abdel-Hadi 2014. Islam and civilization pluralism between the means of dialogue and the ethics of coexistence, Civilization Center for the Development of Islamic Thought, Beirut.

Ali, Haider Ibrahim and others 2002, The Crisis of Minorities in the Arab World, House of Contemporary Thought, Beirut.

Al-Khatibi, Abdel-Kabir 1999. Politics and Tolerance, Translated by: Ezz El-Din El Kettani Al-Idrisi, Supreme Council of Culture, The National Project for Translation, Cairo.

Al-Khayyat, Abd al-Aziz 1981. The Interdependent Society in Islam, 2nd Edition, The Message Foundation, Beirut.

Al-Khouli, Sanaa 1980. Principles of Sociology, University Library, Alexandria.

Allam, Wael, 2001. Dictionary of Minority Rights Protection in International Law, Volume 2, Dar Al-Nahda Al-Arabiya, Cairo.

Al-Osaily, Abdullah Abdel-Moneim 2012. Pluralism and Cultural Coexistence in Light of Islamic Law, Conference on Pluralism and the Right to Difference from an Islamic Perspective and the Role of Universities in It, Palestine.

Al-Qarni, Ayed Abdullah, 2002. Paragon Society, Dar Ibn Hazm for Printing and Publishing, Beirut

Al-Qutbi, Hussein, 2001. The culture of love versus the culture of hatred, publications of the Iraqi Organization for Development and Peaceful Coexistence.

Al-Sarjani, Ragheb, 2010. The Art of Prophetic Interactions with Non-Muslims, Dar Al-Aqlam for Publishing, Distribution and Translation, Cairo.

Al-Sayeh, Ahmad Abdel-Rahim, 1981. Highlights of Islamic Civilization, 1st Edition, Dar Al-Liwaa

Al-Yafei, Abdel-Fattah Bin Saleh, 2011. Human Coexistence and Religious Tolerance in Islam, 1st Edition, Al-Risala Foundation, Beirut.

Aqaq, Badria. 2013. Defining the concept of minorities in international law, House of Thought and Law, Mansoura, Egypt.

Ayesh, Muhammad Saeed Ahmad 2014. The Islamic Society: Among the Predictions of Weakness and Advancement Factors, Osama House for Publishing and Distribution, Amman - Jordan.

Ismail, Zaki Muhammad, 2002, Anthropology and Islamic Thought, Zahraa House, Riyadh. 
Khalil, Fouad 2008. Society, order and environment in the subject of sociology and its problems, 1st Edition, Dar Al-Farabi, Beirut.

Mandour, Muhammad Abd al-Rahman 1989. Peaceful coexistence between Muslims and others within one state, Dar Al-Salam for printing and publishing, Cairo.

Massad, Nevin Abdel-Moneim, 1988. Minorities and Political Stability in the Arab World, Center for Research and Strategic Studies, Faculty of Economics and Political Science, Cairo University, Egyptian Renaissance Library, Cairo.

Muhammad, Jamal al-Din Attia, 2007. Towards a new jurisprudence for minorities, Dar Al-Salam for printing, publishing and distribution, Cairo.

Ratasani, Ali 2013. Multiculturalism, Arab Kalimat House for Publishing and Distribution, Egypt.

Safi al-Din, Bilal 2009. The concept of tolerance in Islam and its relation to the concept of duty, the Conference on Religious Tolerance, Damascus.

Syed Ahmed, Gharib Muhammad and others 1988. Rural and Urban Meeting, University Knowledge House, Alexandria.

The Holy Quran

Yusef, Ali. Muslims between religious and political citizenship, Dar Al-Ma'arif Al-Hakamiah, Morocco. 
The Non-Muslim Minorities in the Islamic Community Anthropological Study According to the Methodology of the Prophet Mohmmed (Peace be Upon Him) in the Communal Peace

\title{
QUSAY RYAAD KANAN
}

\begin{abstract}
People differ in their nature because the difference is one of the origins of their creation and that the life we live is based on differences, contradiction and opposites. This is what God Almighty deposited in man and the wisdom of having made this human being the most honorable creatures and successors on earth.

Since God sent His last messengers fourteen centuries ago, Islam considered the human rights of every human being of any race, of any religion and of any region, based on its philosophy of honoring man in terms of human being and rights prescribed in Islam.

The rights of minorities in the Islamic community are confirmed rights in Islam, although unfortunately; there are those, opponents of Islam, who want to doubt that to make the issue of minorities an issue to stand in the face of the arbitration of Islamic law in Islamic societies of our time.

In this study, we tried to find out the way the Muslims society deal with non-Muslim minorities and how these behaviors were based on the principles emphasized and inspired by the best examples of communal peace and cultural coexistence, Prophet Mohamed (Peace be Upon him,) in his actions and words with others.

Minorities-

Community-

coexistence-

tolerance Communal Peace
\end{abstract}

